\title{
HAZEBROOK
}

\section{Containment Data Report}

\author{
Billy Hudson \\ Ted Stubbs \\ Ray Heinle
}

December 1994

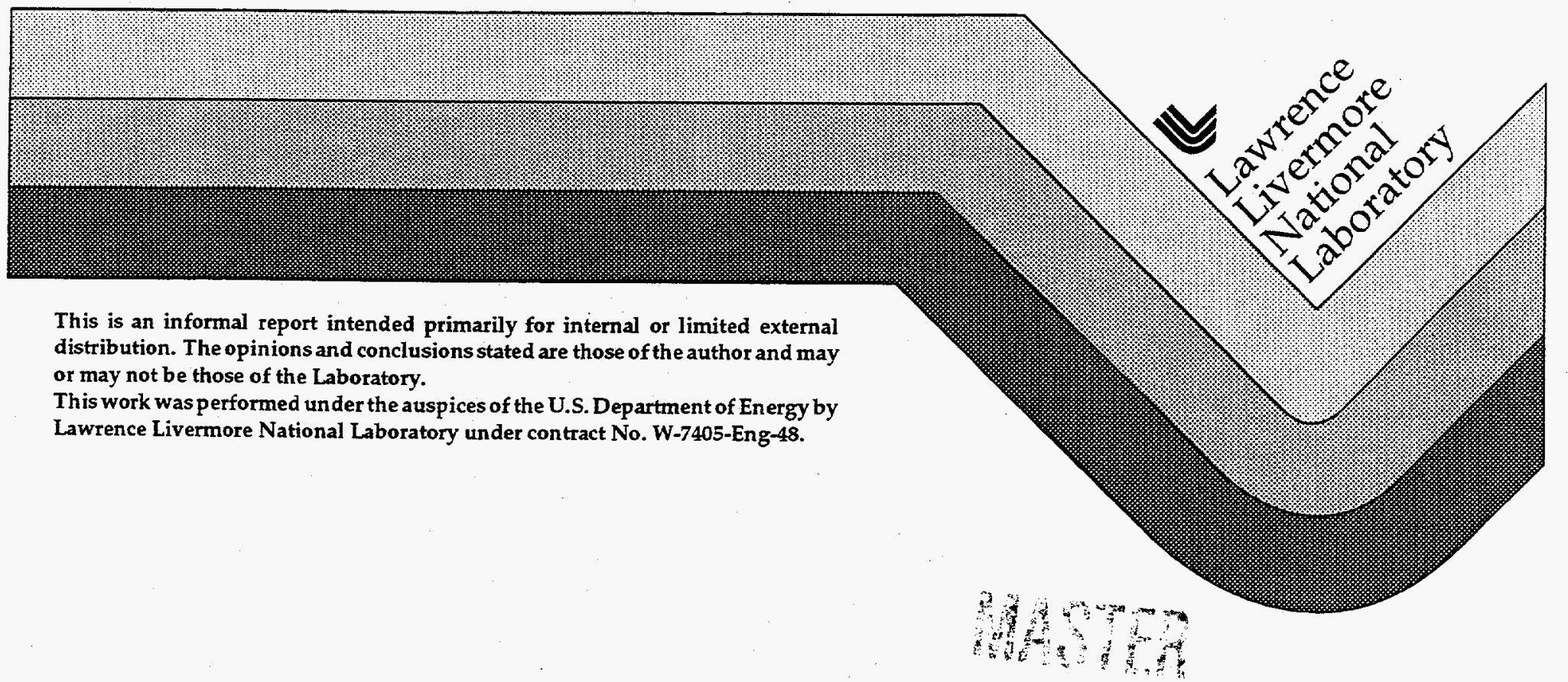




\section{DISCLAIMER}

This document was prepared as an account of work sponsored by an agency of the United States Government. Neither the United States Government nor the University of California nor any of their employees, makes any warranty, express or implied, or assumes any legal liability or responsibility for the accuracy, completeness, or usefulness of any information, apparatus, product, or process disclosed, or represents that its use would not infringe privately owned rights. Reference herein to any specific commercial product, process, or service by trade name, trademark, manufacturer, or otherwise, does not necessarily constitute or imply its endorsement, recommendation, or favoring by the United States Government or the University of California. The views and opinions of authors expressed herein do not necessarily state or reflect those of the United States Government or the University of California, and shall not be used for advertising or product endorsement purposes.

This report has been reproduced

directly from the best available copy.

Available to DOE and DOE contractors from the

Office of Scientific and Technical Information

P.O. Box 62, Oak Ridge, TN 37831

Prices available from (615) 576-8401, FTS 626-8401

Available to the public from the

National Technical Information Service

U.S. Department of Commerce

5285 Port Royal Rd.

Springfield, VA 22161 


\section{DISCLAIMER}

This report was prepared as an account of work sponsored by an agency of the United States Government. Neither the United States Government nor any agency thereof, nor any of their employees, make any warranty, express or implied, or assumes any legal liability or responsibility for the accuracy, completeness, or usefulness of any information, apparatus, product, or process disclosed, or represents that its use would not infringe privately owned rights. Reference herein to any specific commercial product, process, or service by trade name, trademark, manufacturer, or otherwise does not necessarily constitute or imply its endorsement, recommendation, or favoring by the United States Government or any agency thereof. The views and opinions of authors expressed herein do not necessarily state or reflect those of the United States Government or any agency thereof. 


\section{DISCLAIMER}

Portions of this document may be illegible in electronic image products. Images are produced from the best available original document. 
Classification Guide

COK-88-024

NV-89-18

TCG-WT-1

TCG-WT-1

TCG-WT-1

TVG-WT-1

TCG-WT-1

TCG-WT-1

TCG-WT-1

TCG-WT-1

TCG-WT-1

TCG-WT-1

TCG-WT-1

TCG-WT-1
Topic Number

1.5.6

1113

1121

1210

1260

1413

1452

1831

1843

1925

3542.3

4810

4820
Subiect

Event announcement

Event announcement

Contractor identification

Personnel identification

Geology

Crater (map)

Statement concerning venting

Event announcement

Depth of burial

Stemming material, amount,etc

Diagnostic canister dimensions

Ground motion

Radiation measurement

Acceleration, pressure, temperature measurement 
HAZEBROOK Instrumentation Summary

\begin{tabular}{|c|c|c|c|}
\hline Instrumentation & Fielded & $\begin{array}{c}\text { Data } \\
\text { Return }\end{array}$ & $\begin{array}{l}\text { Present in } \\
\text { this Report }\end{array}$ \\
\hline Plug Emplacement & yes & yes & yes \\
\hline Radiation & yes & yes & yes \\
\hline \multicolumn{4}{|l|}{ Pressure } \\
\hline Stemming & yes & yes & yes \\
\hline Challenge & yes & yes & yes \\
\hline Cavity & yes & yes & yes \\
\hline Atmospheric & yes & yes & yes \\
\hline \multicolumn{4}{|l|}{ Motion } \\
\hline Free field & no & - & - \\
\hline Surface & yes & yes & yes \\
\hline Plug & yes & yes & yes \\
\hline Stemming & yes & yes & yes \\
\hline Surface casing & no & - & - \\
\hline Emplacement pipe & no & - & - \\
\hline Recording trailer & yes & yes & yes \\
\hline Hydroyield (a) & yes & yes & no \\
\hline Collapse $^{(b)}$ & yes & yes & yes \\
\hline Stress & no & - & - \\
\hline Strain & no & - & - \\
\hline Other Measurements $(c)$ & no & - & - \\
\hline
\end{tabular}

(a) EXCOR/CORRTEX in emplacement hole.

(b) EXCOR measurement in emplacement hole.

(c) Motion of the recording trailer

\section{Event Personnel}

Containment Physics
B. Hudson
E. Woodward
J. Kalinowski
T. Stubbs

Instrumentation

$\begin{array}{ll}\text { C. Cordill } & \text { LLNL } \\ \text { M. Hatch } & \text { EG\&G/AVO } \\ \text { L. Farthing } & \text { EG\&G/NVO } \\ \text { R. Spilsbury } & \text { EG\&G/NVO }\end{array}$




\section{Contents}

1. Event Description

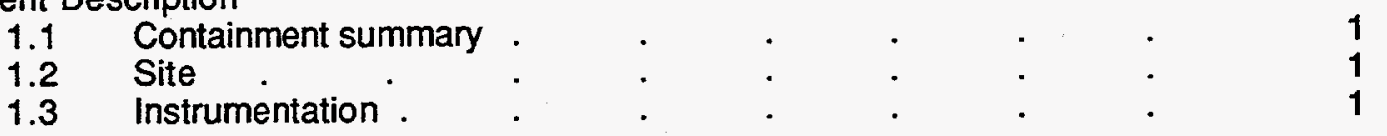

2. Emplacement

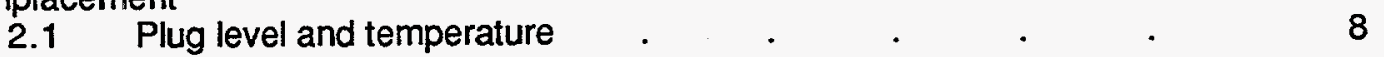

3. Stemming Performance

3.1 Radiation and Pressure . $\quad . \quad$. . . . $\quad$. 14

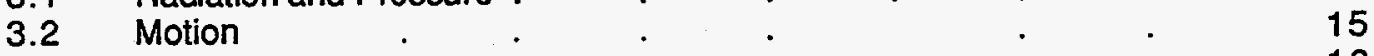

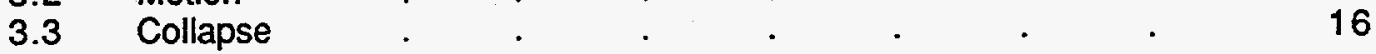

4. Other Measurements

4.1 Motion at the LLNL trailer park . $\quad$. $\quad$. $\quad$. $\quad 37$

References . . . . . . . . . . . . . . . 43 


\section{Event Description}

\subsection{Containment summary}

The HAZEBROOK event was detonated in hole U10bh of the Nevada Test Site (figure 1.1). Detonation time was 7:20 AM PST on February 3, 1987. No subsidence was observed. Radiation arrivals were detected to a depth of $122 \mathrm{~m}$ in the emplacement hole; however, no radiation was detected above ground. The HAZEBROOK event containment was satisfactory.

1.2 Site.

A magnified geologic map showing some of the surface features near the U10bh site is shown in Figure 1.2. The device had a burial depth of $186 \mathrm{~m}$ in Area 10 tuffs about $390 \mathrm{~m}$ above the static water level (SWL), as shown in the geologic cross sections of figure $1.3^{(1)}$.

Stemming of the $2.44 \mathrm{~m}$ diameter emplacement hole followed the plan shown in figure 1.4. A log of the stemming operations was maintained by Holmes \& Narver( ${ }^{(2)}$.

\subsection{Instrumentation}

Figure 1.5 is a schematic layout of the instrumentation in hole $\mathrm{U} 10 \mathrm{bh}$, designed to monitor the stemming emplacement procedures and performance on the HAZEBROOK event.

For quality assurance during emplacement, each of the four sanded gypsum concrete (SGC) plugs was monitored with arrays of thermistors and conductivity probes.

The coarse stemming below each of the four SGC plugs was instrumented with pressure and radiation stations. A pair of gauges was mounted to monitor the pressure challenging the bottom plug. Cavity pressure was monitored by two sets of three pressure transducers. One of the sets was mounted as an addendum to a gas sampling hose and the other was a standalone system. Each transducer consisted of a 10,000 psi rated gage connected to a waterfilled, stainless steel tube extending from the gage (at a depth of about $145 \mathrm{~m}$ ) to near the level of the working point. Both sets were pressurized with nitrogen to about 4000 psi at 1 second before detonation. 
Sensitive pressure stations were also fielded below the top three plugs and in the ground surface 15.24 from Surface Ground Zero (SGZ) to study the permeability of the SGC plugs and geologic formation. These stations were monitored by Paroscientific ${ }^{\circledR}$ data acquisition systems that transmitted the data in digital form to be recorded on Waveteck 6000 instruments housed in an auxiliary recording facility (Van 8).

Vertical motion was monitored in the stemming at the three deepest standard pressure \& radiation stations, in the bottom plug, and at $0.61 \mathrm{~m}$ depth in the ground surface, $15.24 \mathrm{~m}$ from SGZ. Triaxial motion of the recording trailer was also monitored.

Data from each of the transducers above (with the exception of the sensitive pressure stations) were transmitted to the recording trailer by an analog system and recorded on magnetic tape.

Hydrodynamic yield of the device and cavity subsidence was monitored by an EXCOR/CORRTEX cable (labeled "CLIPER/CORRTEX" in figure 1.5) fielded in the emplacement hole. Results of the hydrodynamic yield measurements are reported elsewhere ${ }^{(3)}$.

A brief history of the fielding operations of the instrumentation (including the emplacement pipe strain measurements) is given in reference 4. Further details of the instrumentation are given in reference 5 . 


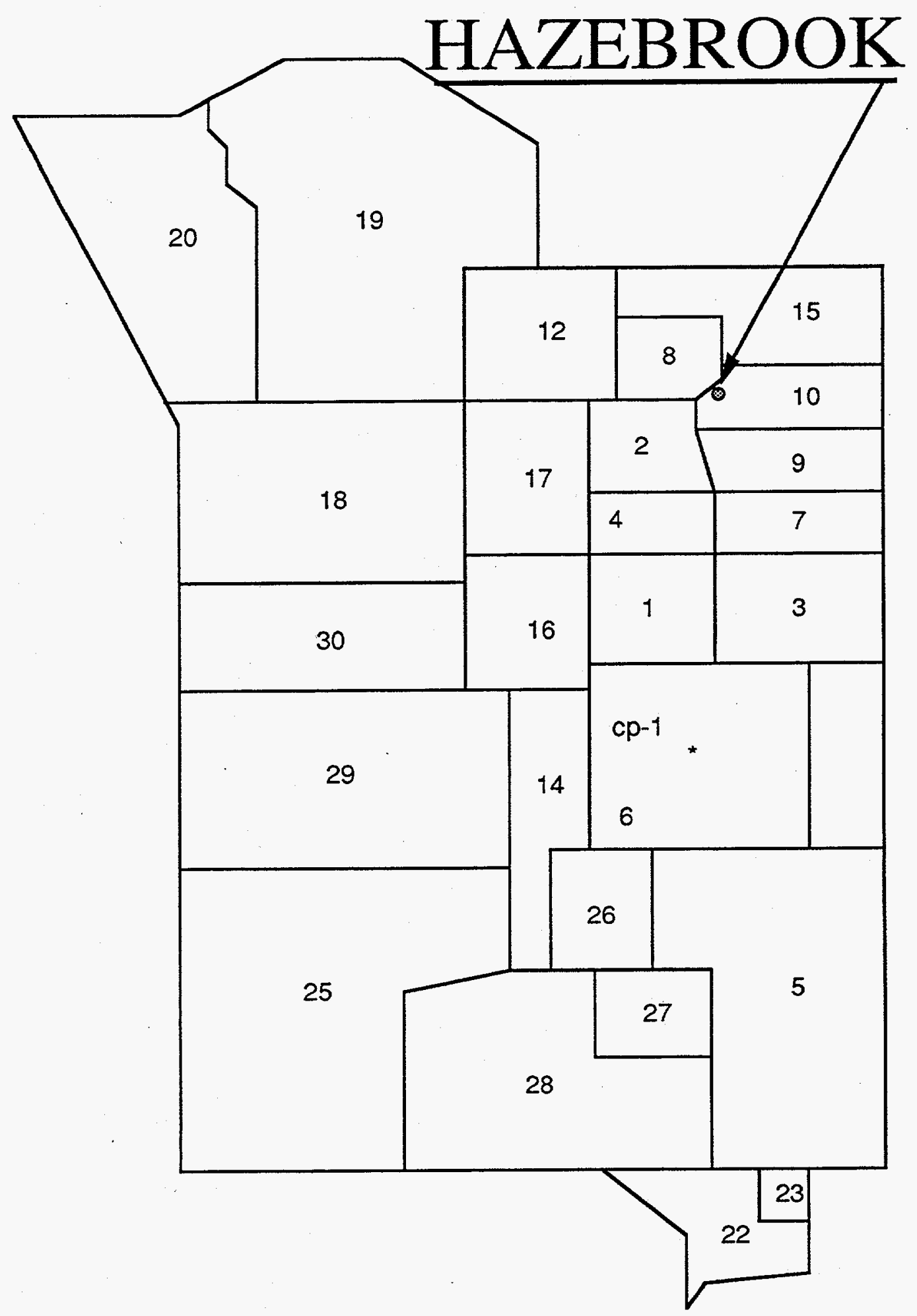

Figure 1.1 Map of the Nevada Test Site indicating the location of hole 10bh. 


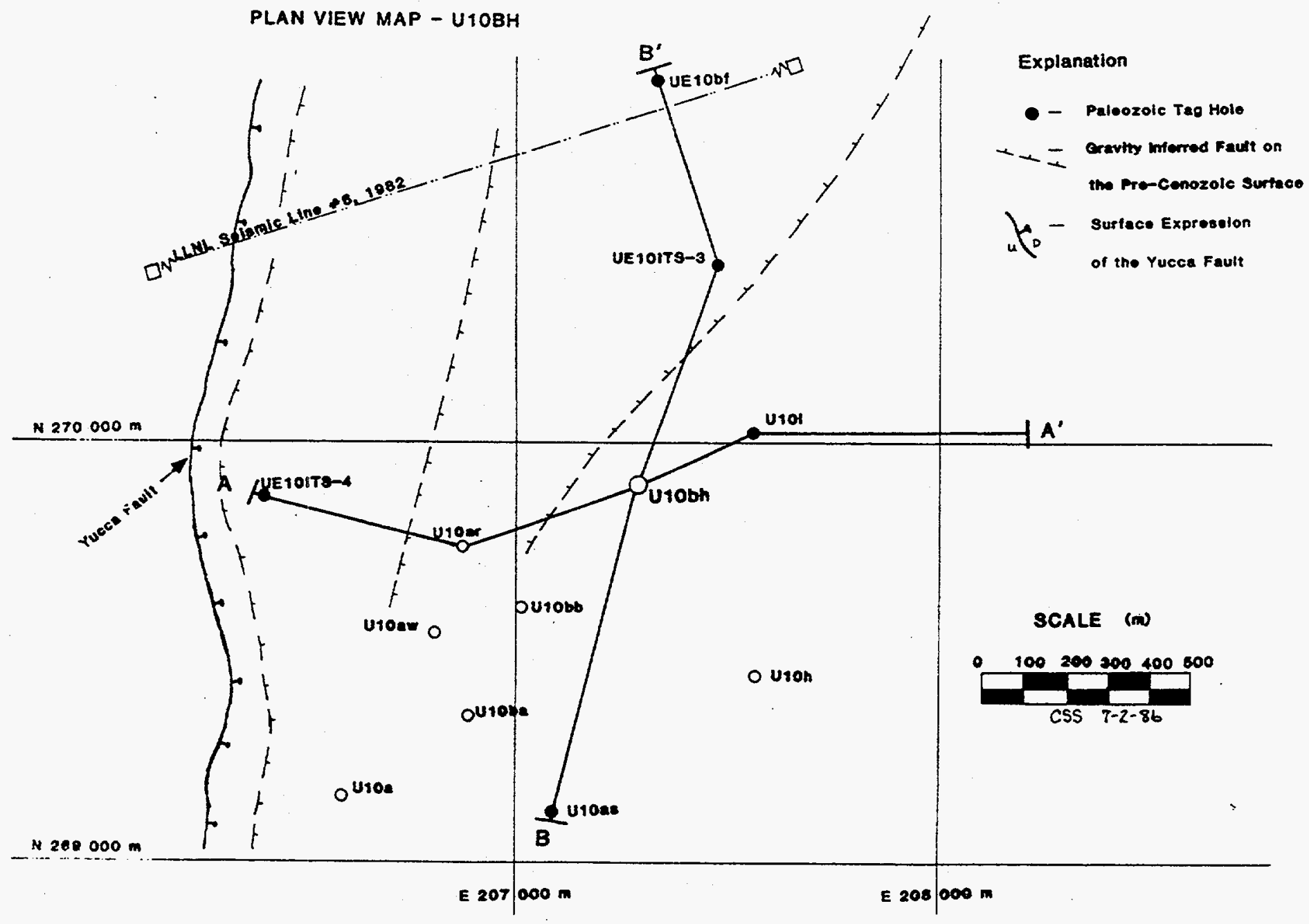

Figure 1.2 Geologic Map of the region near hole U10bh. 

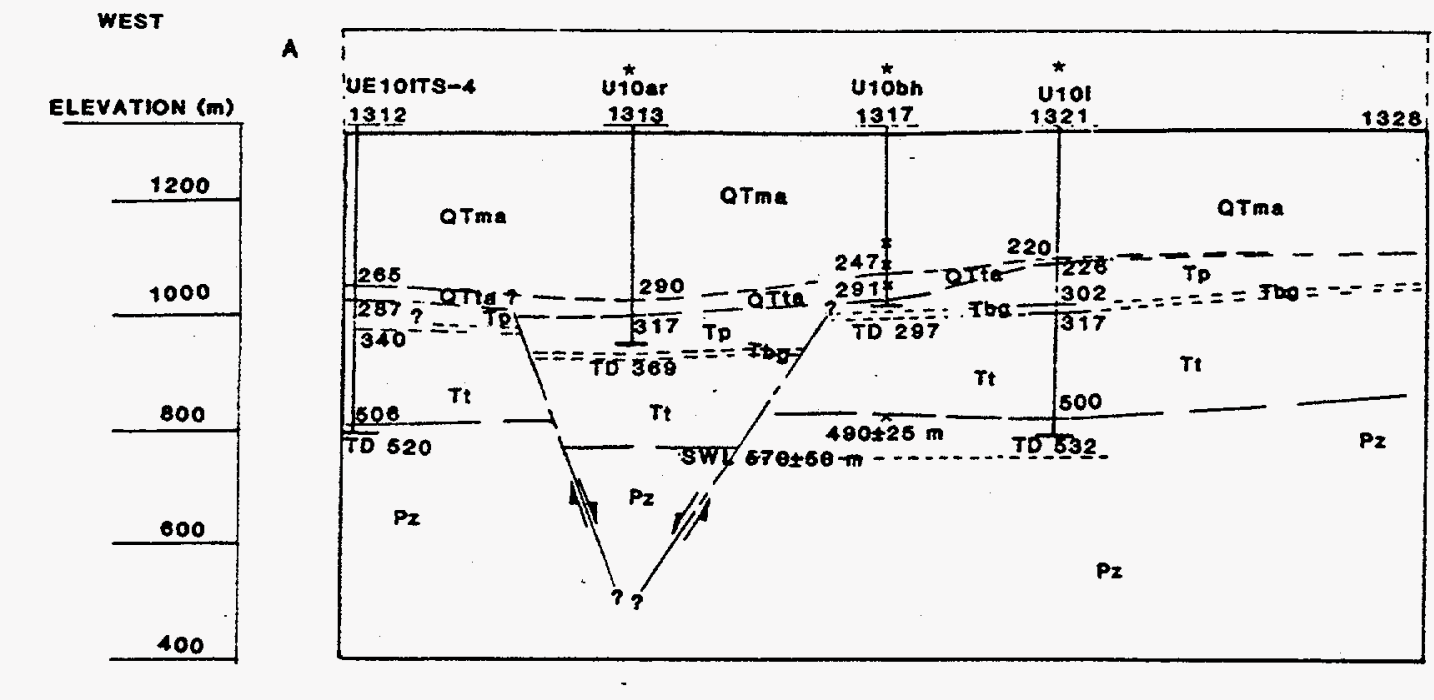

$A^{*}$

EAST

U10bh Geologic Cross Section A-A'

EXPLANATION

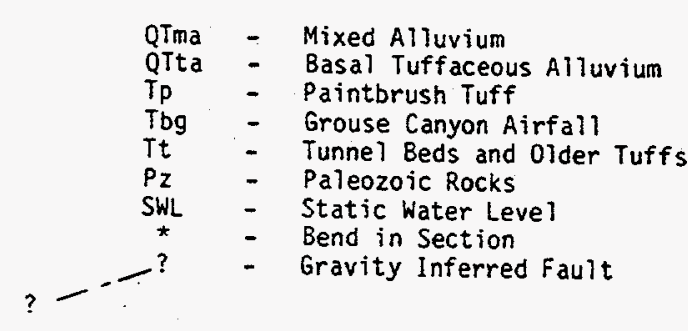

SOUTH

NORTH

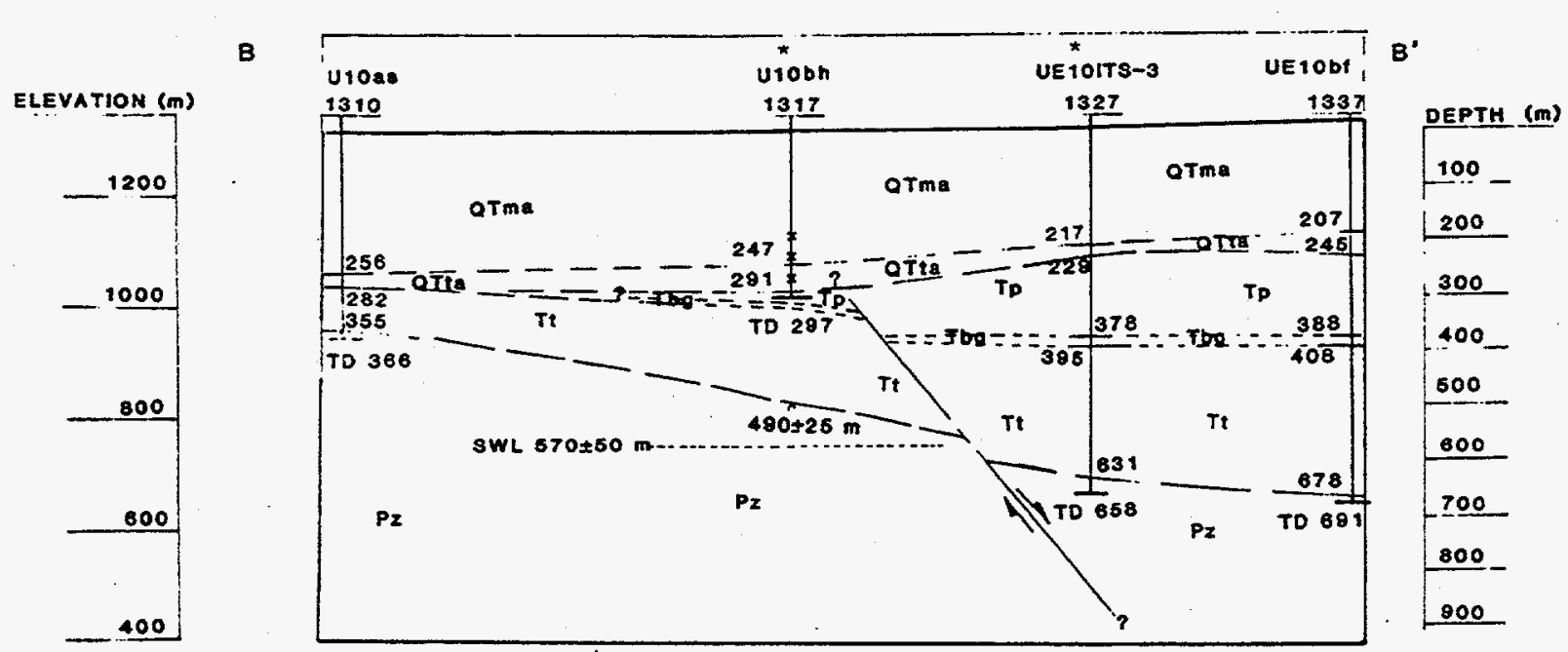

U10bh Geologic Cross Section B-B'

Figure 1.3 Geologic cross section through hole U10bh. 


\section{HAZEBROOK}
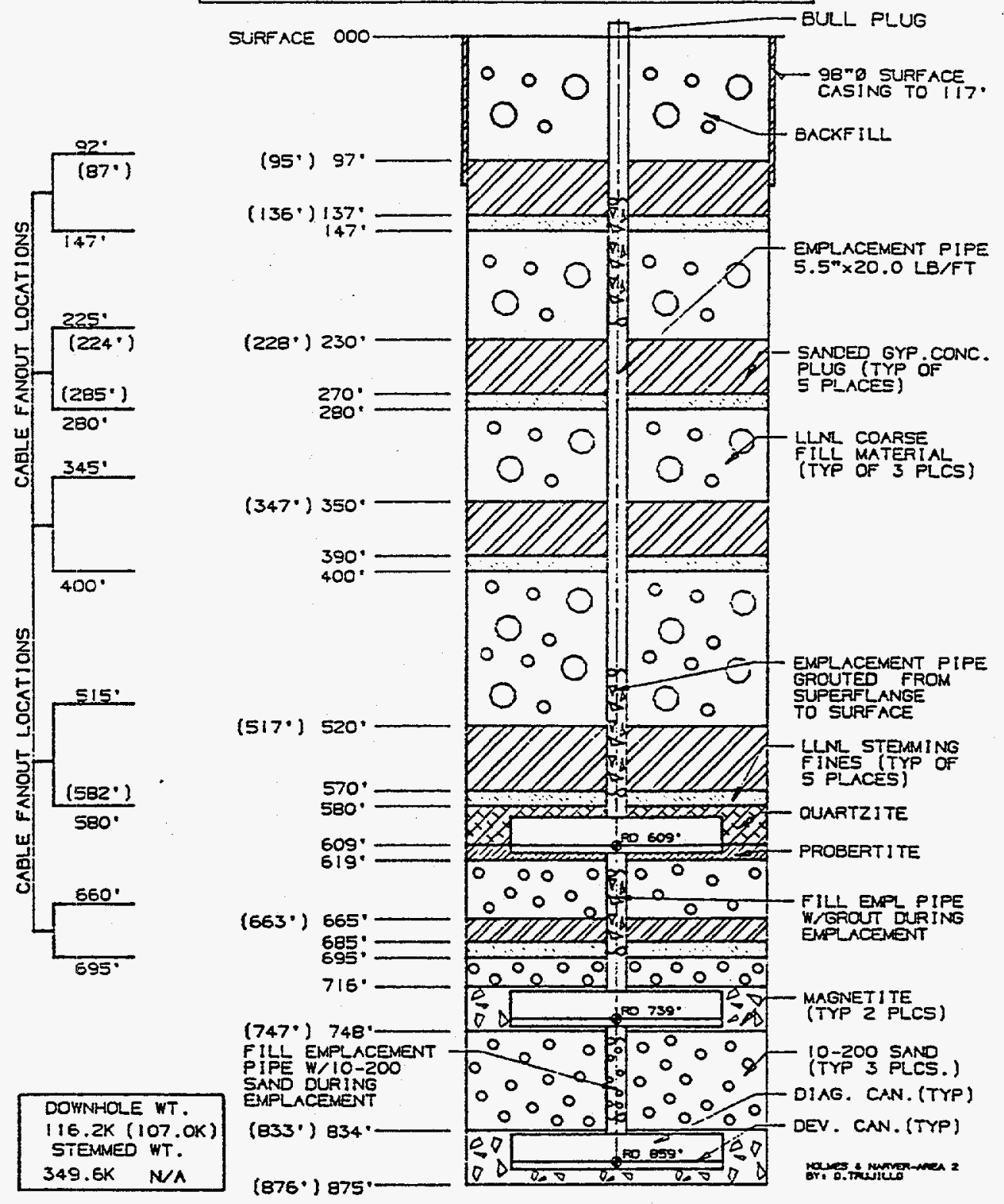

Figure 1.4 As-built stemming plan for hole U10bh. 


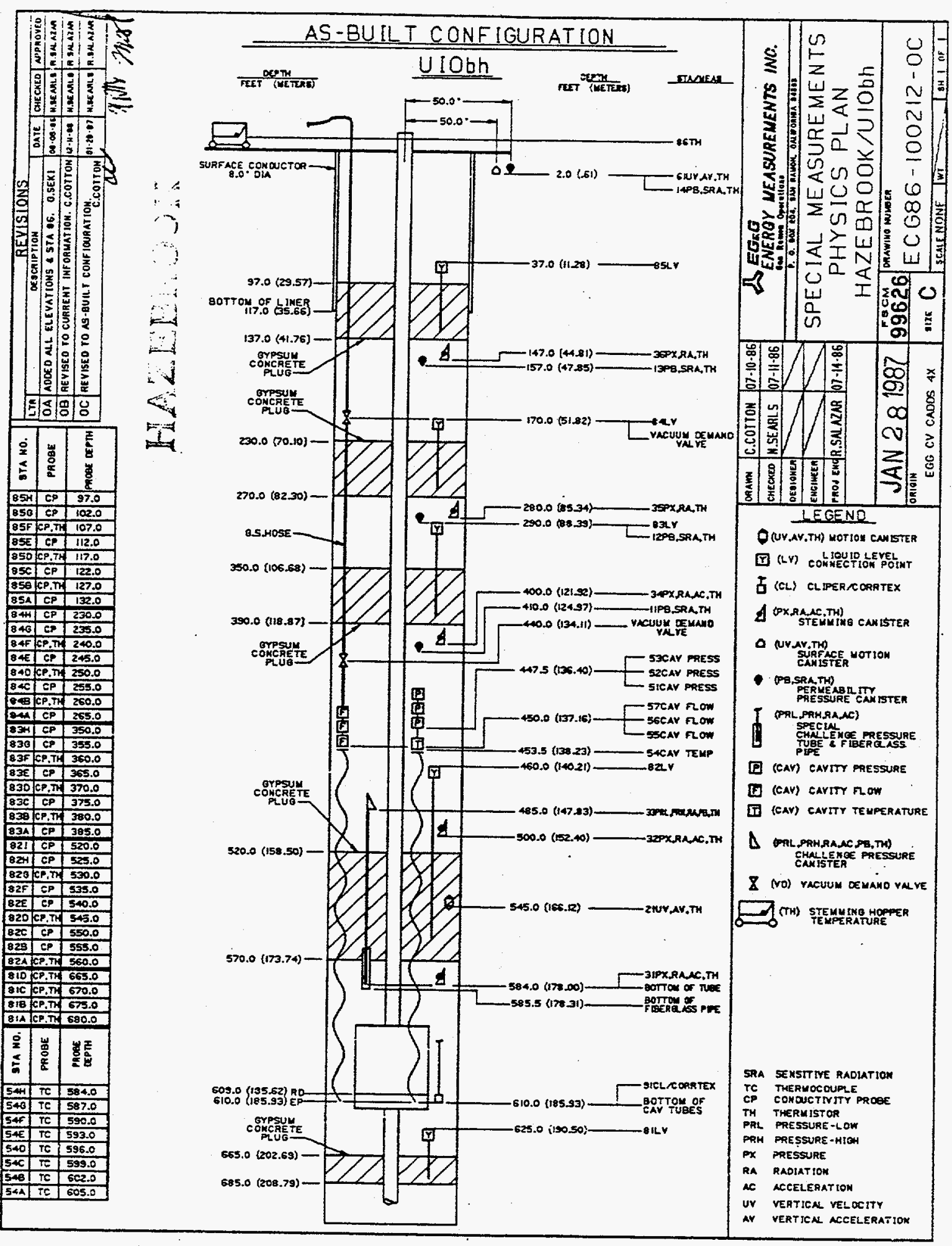

Figure 1.5 As-built containment instrumentation plan for the HAZEBROOK event emplacement hole U10bh. 


\section{Emplacement}

\subsection{Plug levels and temperature}

Emplacement of each of the four SGC plugs was monitored with an array of conductivity probes and thermistors. The locations of the probes are tabulated in figure 1.5. Figures 2.12.4 show plots of the SGC emplacement and temperature histories. Open circles indicate the upper and lower boundary positions of the plugs as measured with tag lines while solid circles indicate the positions of the probe stations and the times at which the conductivity probes were activated. Those probes which included temperature sensors are noted in each figure caption. All plugs were emplaced as planned. 


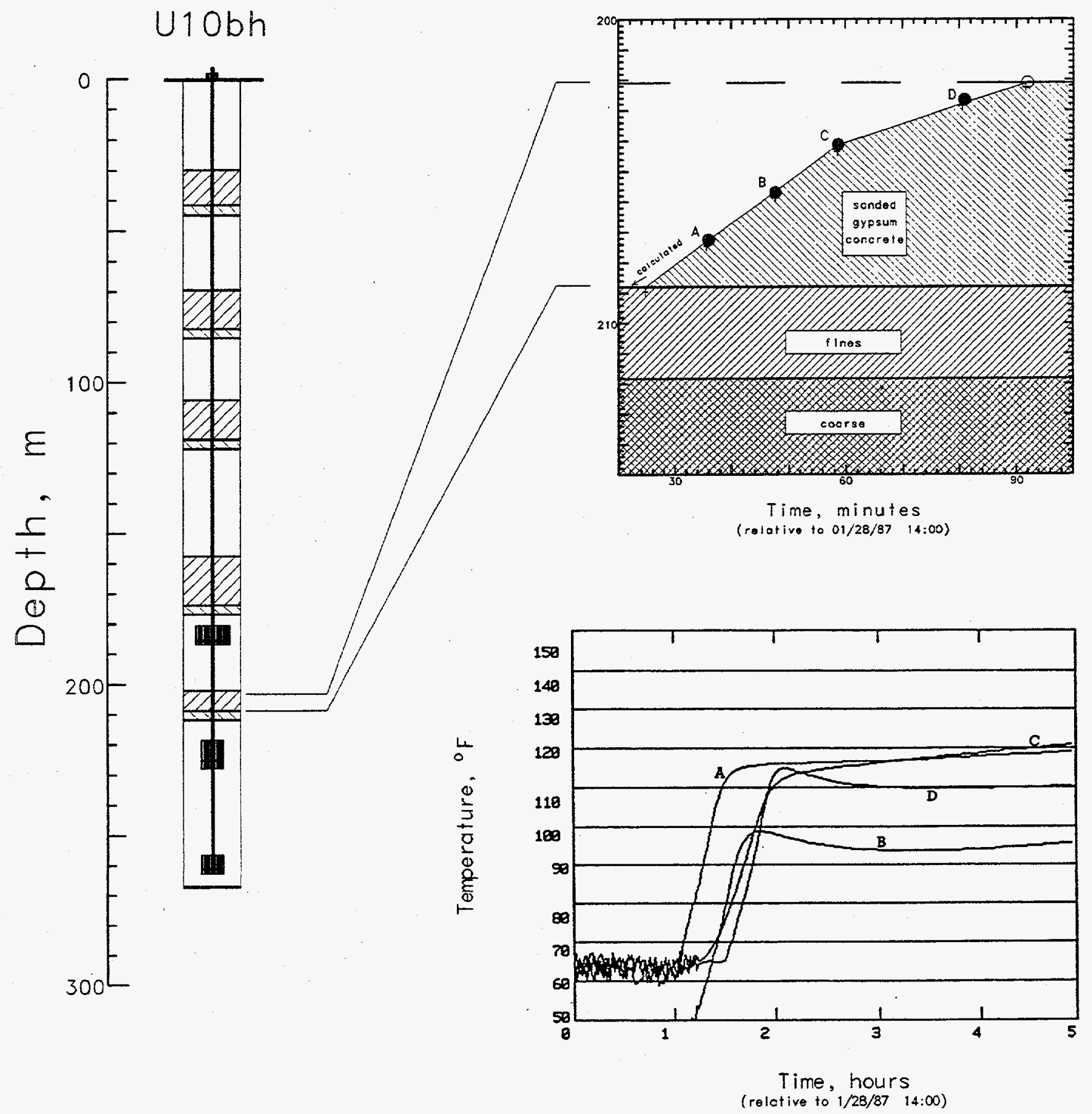

Figure 2.1 Sanded gypsum emplacement for plug \#1. The upper and lower plug boundaries were calculated or determined with a tag line (open circle). Solid symbols indicate the probe elevations. All probes included temperature sensors. 


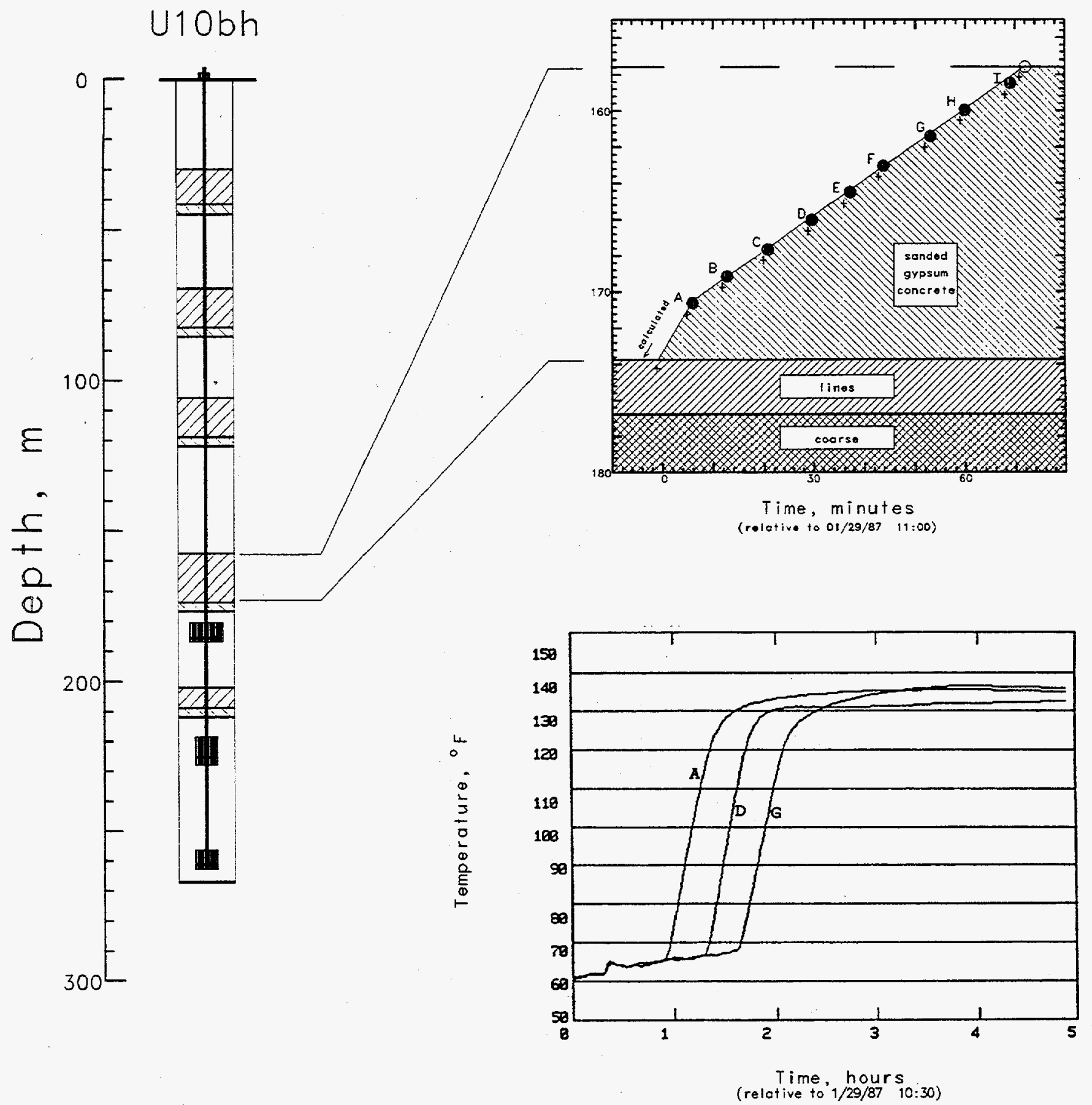

Figure 2.2 Sanded gypsum emplacement for plug \#2. The upper and lower plug boundaries were calculated or determined with a tag line (open circle). Solid symbols indicate the probe elevations. Probes labeled A, D, and $G$ included temperature sensors. 


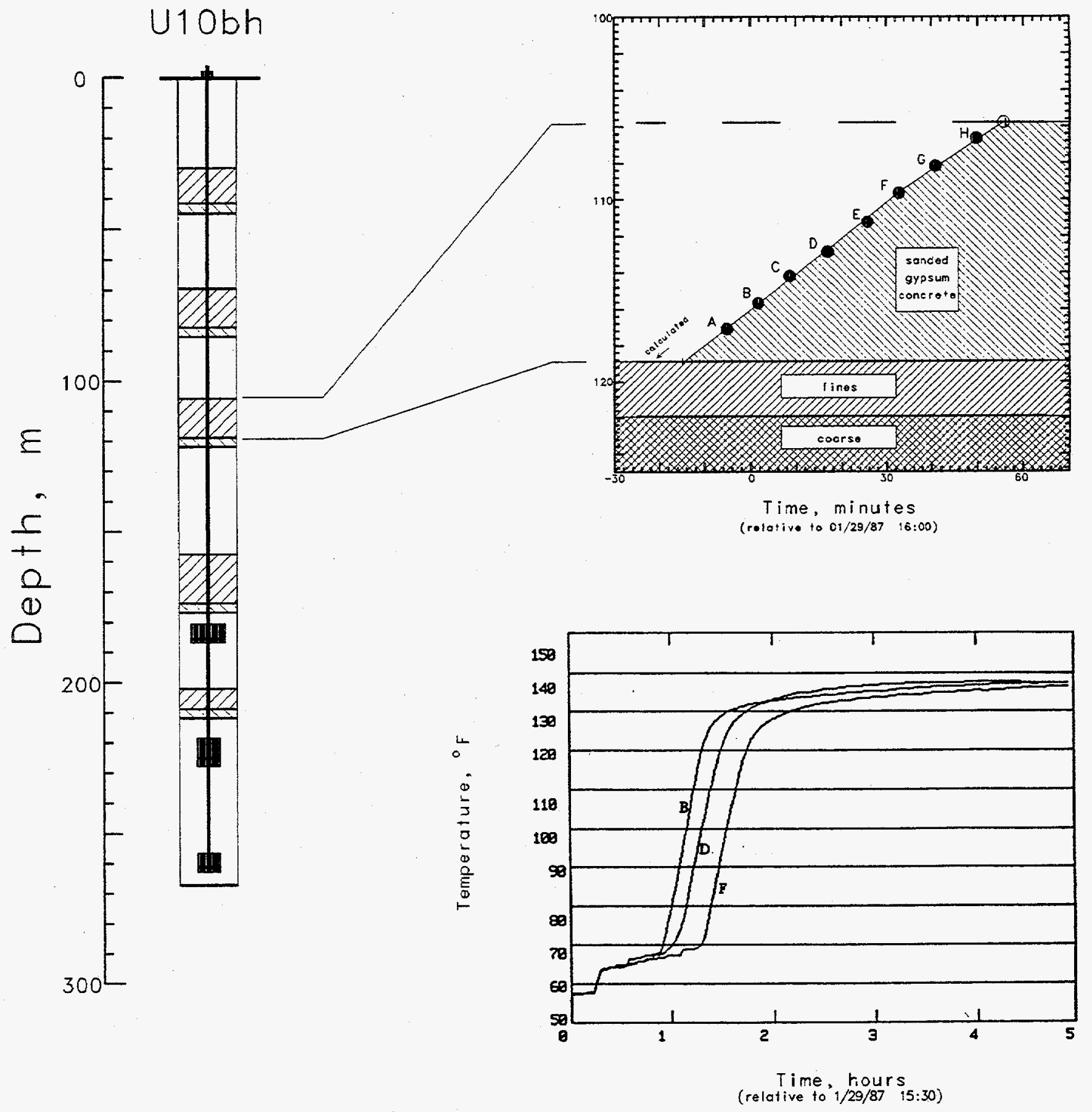

Figure 2.3 Sanded gypsum emplacement for plug \#3. The upper and lower plug boundaries were calculated or determined with a tag line (open circle). Solid symbols indicate the probe elevations. Probes labeled B, D, and F included temperature sensors. 


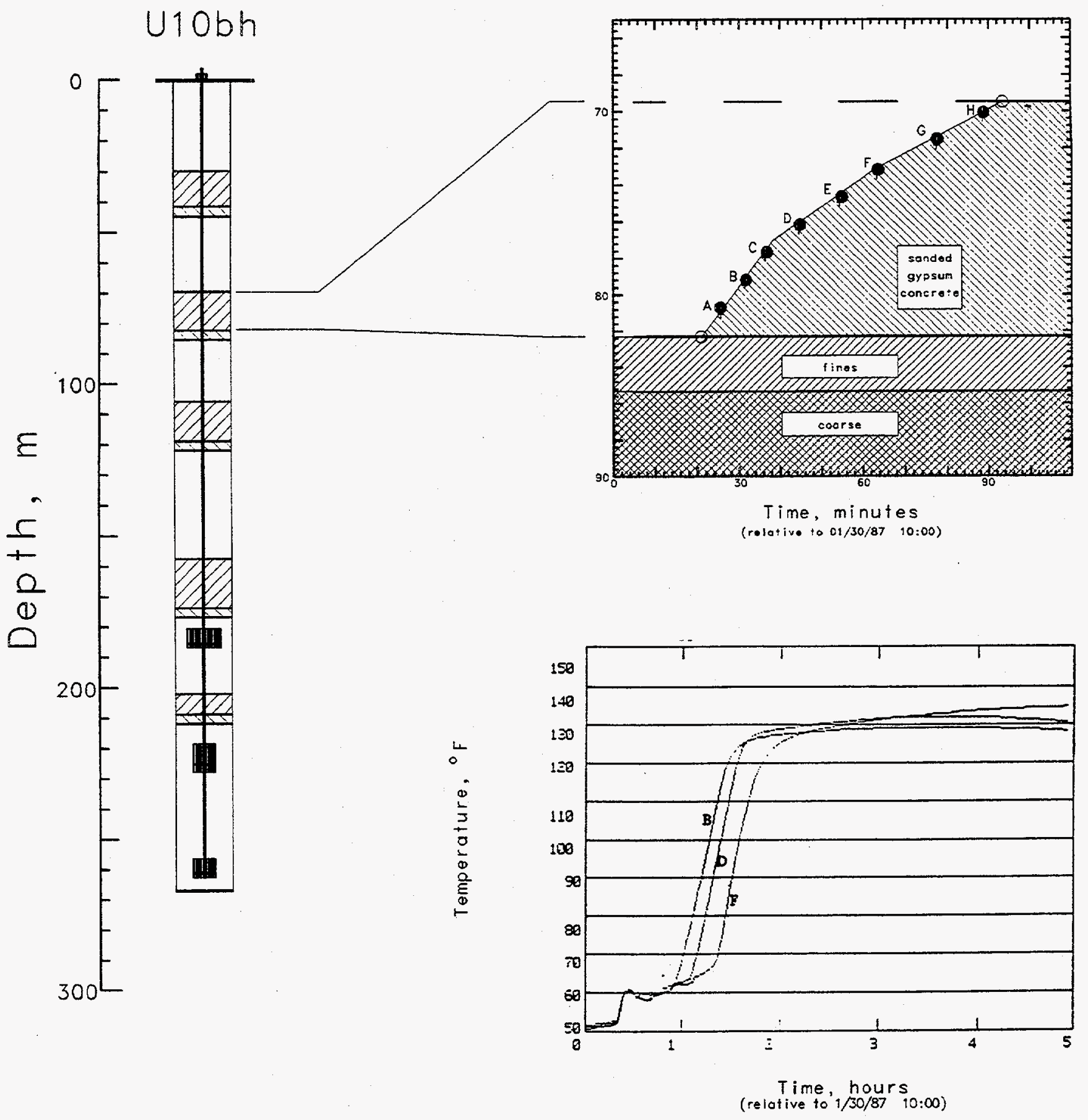

Figure 2.4 Sanded gypsum emplacement for plug \#4. The upper and lower plug boundaries were determined with a tag line (open circles). Solid symbols indicate the probe elevations. Probes labeled $B, D$, and $F$ included temperature sensors. 


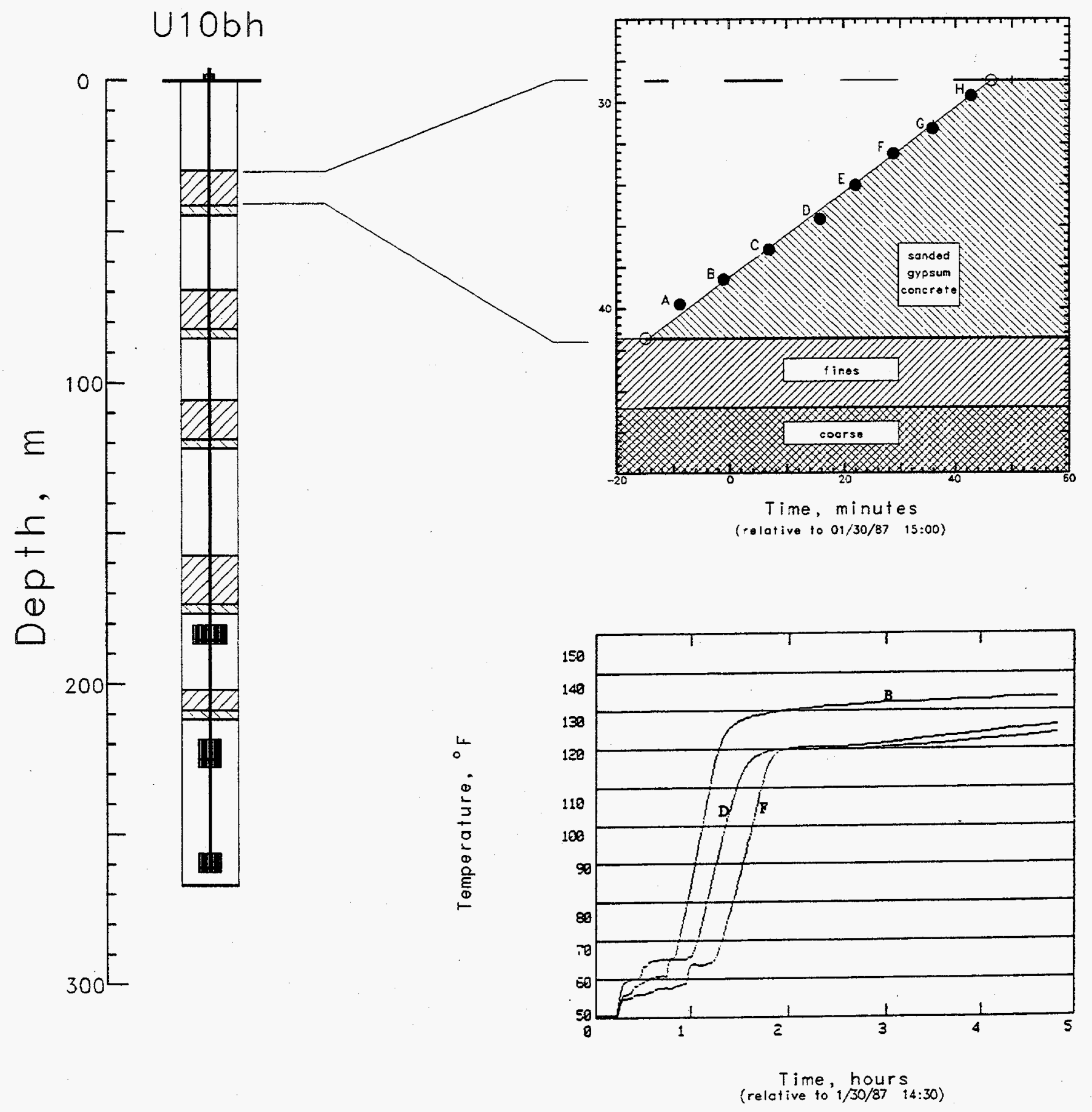

Figure 2.5 Sanded gypsum emplacement for plug \#5. The upper and lower plug boundaries were determined with a tag line (open circles). Solid symbols indicate the probe elevations. Probes labeled $B, D$, and $F$ included temperature sensors. 


\section{Stemming Performance}

\subsection{Radiation and Pressure}

All pressure and radiation data are consistent with satisfactory containment.

As indicated in Figure 1.4, the region below each of the four SGC plugs was monitored by pressure and radiation stations, as was the ground surface, $15.24 \mathrm{~m}$ from SGZ. Signals from these stations were transmitted to the recording trailer in analog form and recorded on magnetic tape.

Pressure and radiation histories, from a few seconds before detonation until recording termination or station failure, are displayed in Figures 3.1-3.6. Radiation was seen in the stemming between the device and the third plug , but no further up the hole. Arrival of radiation immediately above the second plug (just above the device) occurred at less than 30 seconds (figure 3.7 ) with a second surge of radiation propagating through the coarse stemming to the third plug. This second wave of radiation arrived at station 32 at around 2500 seconds and at station 34 about 3000 seconds later.

The lack of any indication of early-time radiation at station 34 and the delayed arrival of the second pulse at both station 33 and 34 (figures 3.2, 3.3, and 3.4) suggests that two different propagation paths were involved. Figure 3.7 shows the early-time pressure on either side of the second plug. A peak difference of about $60 \mathrm{psi}$, occurring nearly 130 seconds after detonation, challenged this plug. The wave form of the radiation in the coarse stemming above this plug (station 32) and that of the radiation measured in the hose through which the challenge pressure was sensed (station 33 ) are also compared in figure 3.7. Except for times of less than 50 seconds and between 220 and 300 seconds, these wave forms are parallel indicating that the source of radiation for these two is the same. The difference in character of the two wave forms suggests that this early-time source was the radioactive gas in the hose leading to station 33 . The delay of the second (late-time) pulse of radiation and its presence at station 34 suggests that its source was flow through or around the second plug. 
Two sets of three transducers were fielded to monitor the gas pressure in the explosionproduced cavity. Each transducer consisted of a 10,000 psi rated pressure gage monitoring a water-filled stainless steel tube extending from the pressure gage to the region of the detonation. The tube had an outer diameter of $6.35 \mathrm{~mm}$ and an inner diameter of $3.17 \mathrm{~mm}$. It was filled with water to inhibit shock closure and wound in a helix having a radius of about $5 \mathrm{~cm}$ and a pitch which approximated the inverse of the expected explosion-produced ground displacement gradient to inhibit loss from ground shear. The tube was pressurized shortly prior to detonation to about 4000 psi with dry nitrogen from a 1.21 reservoir. It was expected that the detonation would vaporize or melt off the end of the tube allowing the water to be expelled, at times long after the shock passage, by the high pressure gas.

One trio of gages $(51,52$, and 53 ) was a stand-alone system and figures 3.8 and 3.9 show both the early time and late time pressure wave forms measured by these gages. The second trio of transducers $(55,56$, and 57$)$ was fielded as a continuation of a Radio Chemistry gas sampling hose in an effort to provide a clear path for the extraction of gas for a yield determination. As shown in figures 3.10 and 3.11 , these transducers did not work as planned. A series of nine temperature sensors was also fielded on this trio (station 54). None of these gages yielded useful information and they are not shown.

A set of four sensitive pressure stations $(11,12,13$, and 14) was fielded in the emplacement hole and on the ground surface, at a range $15.24 \mathrm{~m}$ from SGZ, to investigate the communication of atmospheric pressure with subsurface locations. The data were recorded in an auxiliary trailer (Van 8) which was activated about 35 hours after the shot. Locations of these stations are shown in figure 1.5 and the resulting data are shown in figure 3.12 .

\subsection{Motion}

Vertical acceleration of the stemming was measured on both sides of the second plug and below the third plug (stations 31, 32 and 34) while station 21 monitored the vertical motion of the second plug. The ground surface, at a depth of $0.91 \mathrm{~m}$ and a horizontal range of $15.24 \mathrm{~m}$ from SGZ, was instrumented for vertical acceleration and velocity. Explosioninduced data derived from these stations are shown in figures 3.13-3.18. Characteristics of the motion and of the motion transducers are given in tables 3.1-3.3. 


\subsection{Collapse}

A single reading from the EXCOR transducer indicated a cable break at a depth of $175 \mathrm{~m}$ (just below the bottom plug). This was recorded at $0.2 \mathrm{~s}$ after detonation: the break could have occurred at an earlier time since the EXCOR electronics were disabled until this time. No further breaks were noted in the EXCOR cable (nor in any of the other sensor cables) for as long as data were recorded. A slight disturbance was sensed in plug\#2 (station 21, figure 3.14) at 3.763 hours. The level of this signal was too low to be integrated to any meaningful wave form. 


\section{Table $3.1 \quad$ Summary of Motion}

\begin{tabular}{|c|c|c|c|c|c|c|}
\hline Gauge & $\begin{array}{l}\text { Slant Range } \\
(\mathrm{m})\end{array}$ & $\begin{array}{l}\text { Arrival Time } \\
\text { (ms) }\end{array}$ & $\begin{array}{l}\text { Acceleration } \\
\text { Peak (g) }\end{array}$ & $\begin{array}{c}\text { Velocity Peak } \\
(\mathrm{m} / \mathrm{s})\end{array}$ & $\begin{array}{c}\text { Displacement } \\
\text { Peak (mm) }\end{array}$ & $\begin{array}{l}\text { Displacement } \\
\text { Resid. (mm) }\end{array}$ \\
\hline $31 a v$ & 7.93 & 9.9 & $>1 k$ & 13.3 & 33 & (a) \\
\hline $32 a v$ & 33.53 & 13.8 & 71 & 7.0 & 150 & -130 \\
\hline $34 a v$ & 64.01 & 20.4 & 2.75 & 0.15 & 22 & -35 \\
\hline $21 a v$ & 19.81 & $4.5^{(b)}, 8.6$ & 56 & 2.06 & 33 & $32^{(c)}$ \\
\hline 21 uv & - & - & - & 2.00 & 32 & 27 \\
\hline $61 a v$ & 185.95 & 123 & $0.75,1.5^{(\mathrm{d})}$ & 0.126 & 26 & -57 \\
\hline 61uv & - & - & - & 0.107 & 22 & -65 \\
\hline
\end{tabular}
(a) Transducer destroyed at about $16 \mathrm{~ms}$.
(b) Emplacement pipe-stemming interaction.
(c) Approximate.
(d) Slap-down peak. 


\section{Table $3.2 \quad$ Accelerometer Characteristics}

\begin{tabular}{|c|c|c|c|}
\hline Gauge & $\begin{array}{l}\text { Natural Frequency } \\
(\mathrm{Hz})\end{array}$ & Damping Ratio & $\begin{array}{c}\text { System Range } \\
\left(g^{\prime} s\right)\end{array}$ \\
\hline 31 av & $>2000$ & NA & 1000 \\
\hline $32 a v$ & $>2000$ & NA & 25 \\
\hline $34 a v$ & $>2000$ & NA & 25 \\
\hline $21 a v$ & 600 & 0.65 & 50 \\
\hline 61 av & 250 & 0.75 & 25 \\
\hline
\end{tabular}

Table 3.3 Velocimeter Characteristics

\begin{tabular}{|c|c|c|c|c|c|}
\hline Gauge & $\begin{array}{c}\text { Natural } \\
\text { Frequency } \\
(\mathrm{Hz})\end{array}$ & $\begin{array}{l}\text { Time to } 0.5 \\
\text { Amplitude } \\
\text { (s) }\end{array}$ & $\begin{array}{c}\text { Calibration } \\
\text { Temperature } \\
\left({ }^{\circ} \mathrm{C}\right)\end{array}$ & $\begin{array}{c}\text { Operate } \\
\text { Temperature } \\
\left({ }^{\circ} \mathrm{C}\right)\end{array}$ & $\begin{array}{c}\text { System } \\
\text { Range } \\
(\mathrm{m} / \mathrm{s})\end{array}$ \\
\hline $21 u v$ & 3.606 & 8.28 & 25.80 & 32.62 & 6 \\
\hline 61 uv & 3.515 & 8.37 & 25.81 & 4.57 & 2 \\
\hline
\end{tabular}



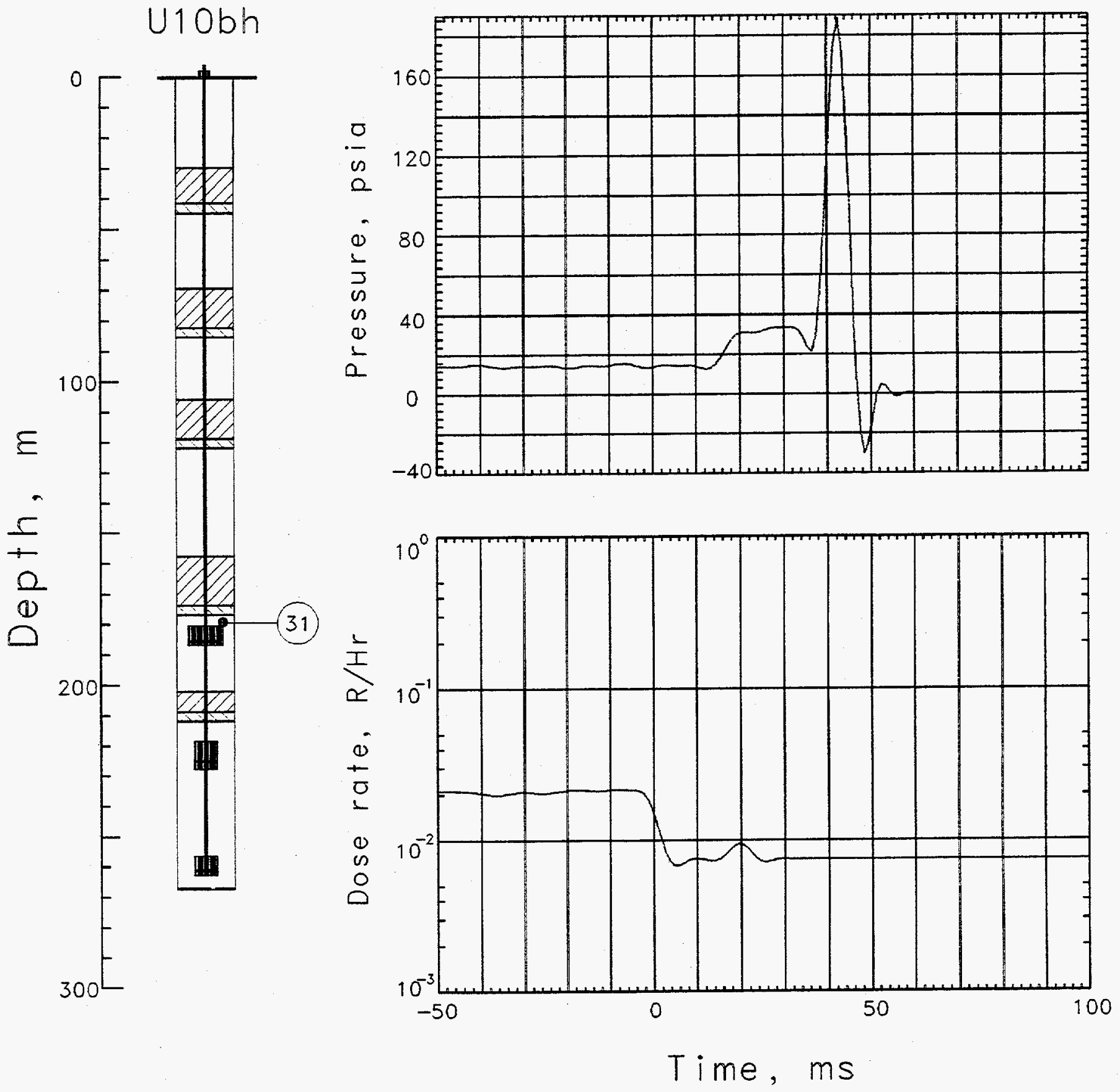

Figure 3.1 Pressure and radiation measured in the coarse stemming below SGC plug \#2 (station 31 at $178 \mathrm{~m}$ depth). Station signals were lost shortly after detonation, presumably due to shock arrival. 

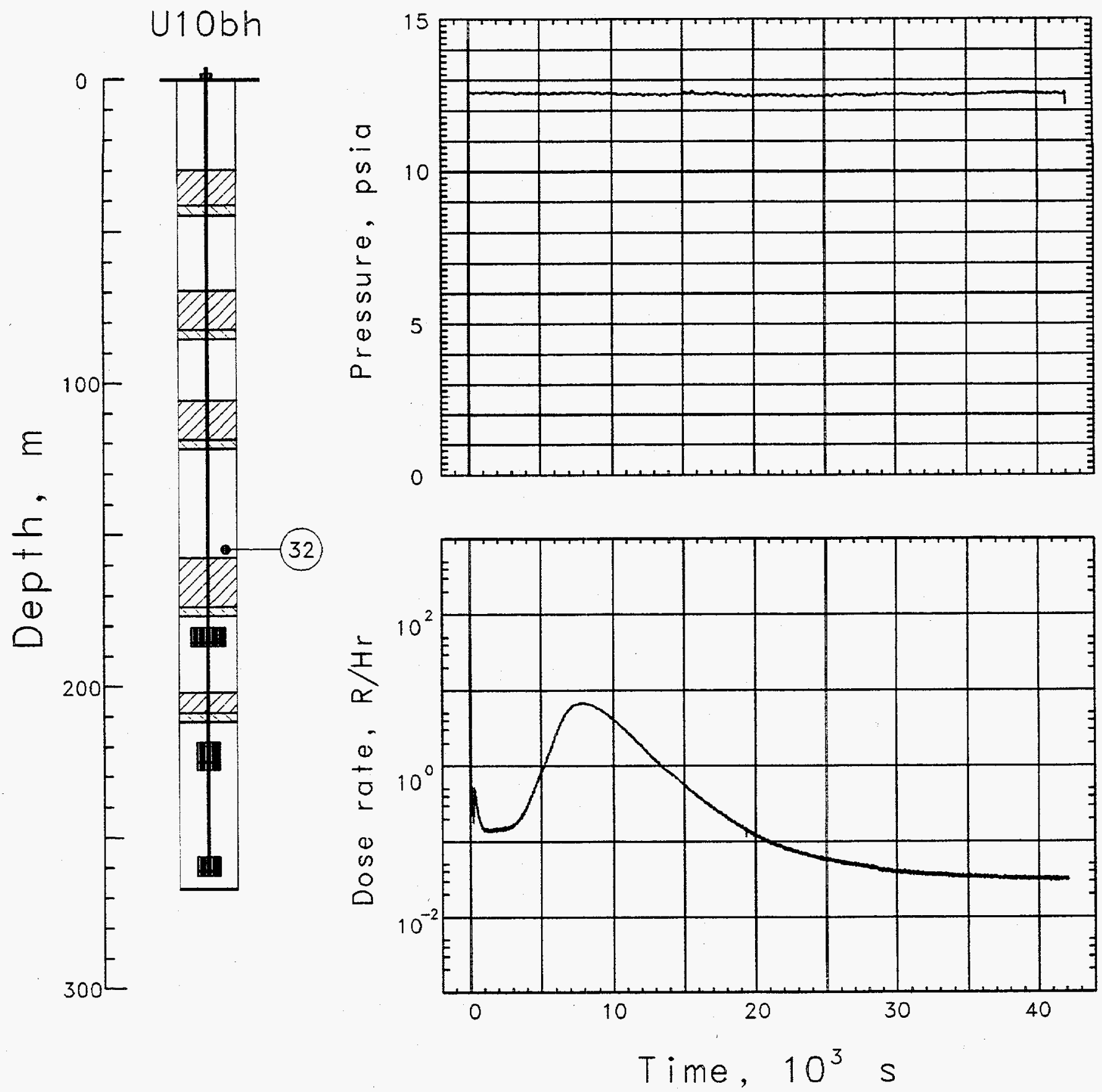

Figure 3.2 Pressure and radiation measured in the course stemming above SGC plug \#2 (station 32 at $152 \mathrm{~m}$ depth). First arrival of radiation is about $22 \mathrm{~s}$. 

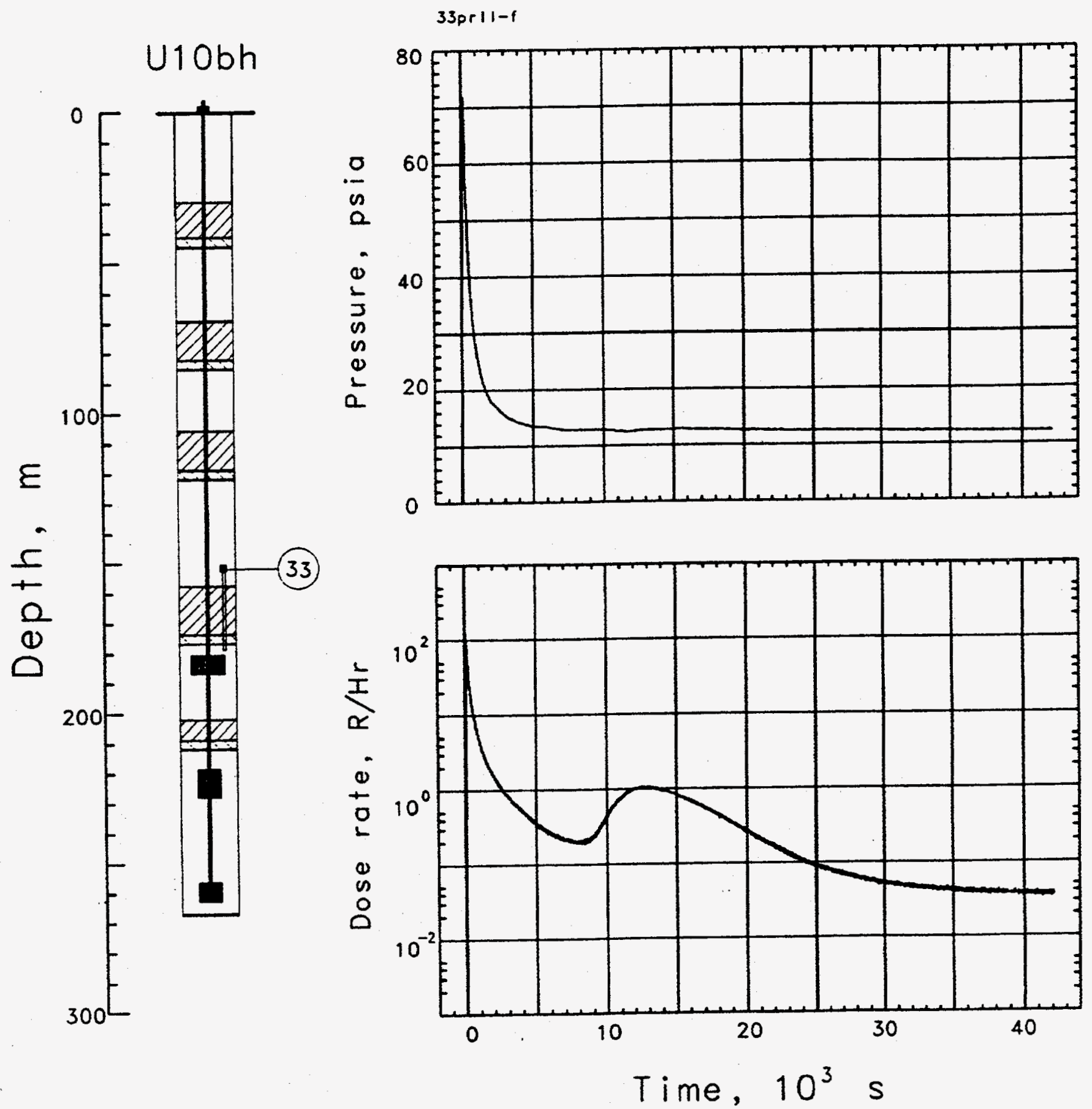

Figure 3.3 Pressure and radiation challenging the second plug as measured in the coarse stemming below it (station 33 at $148 \mathrm{~m}$ depth). Measurements were taken through a hose that penetrated the second plug and extended about $4 \mathrm{~m}$ below it to a depth of $178 \mathrm{~m}$. First arrival of radiation is unknown, but probably before $25 \mathrm{~s}$. 

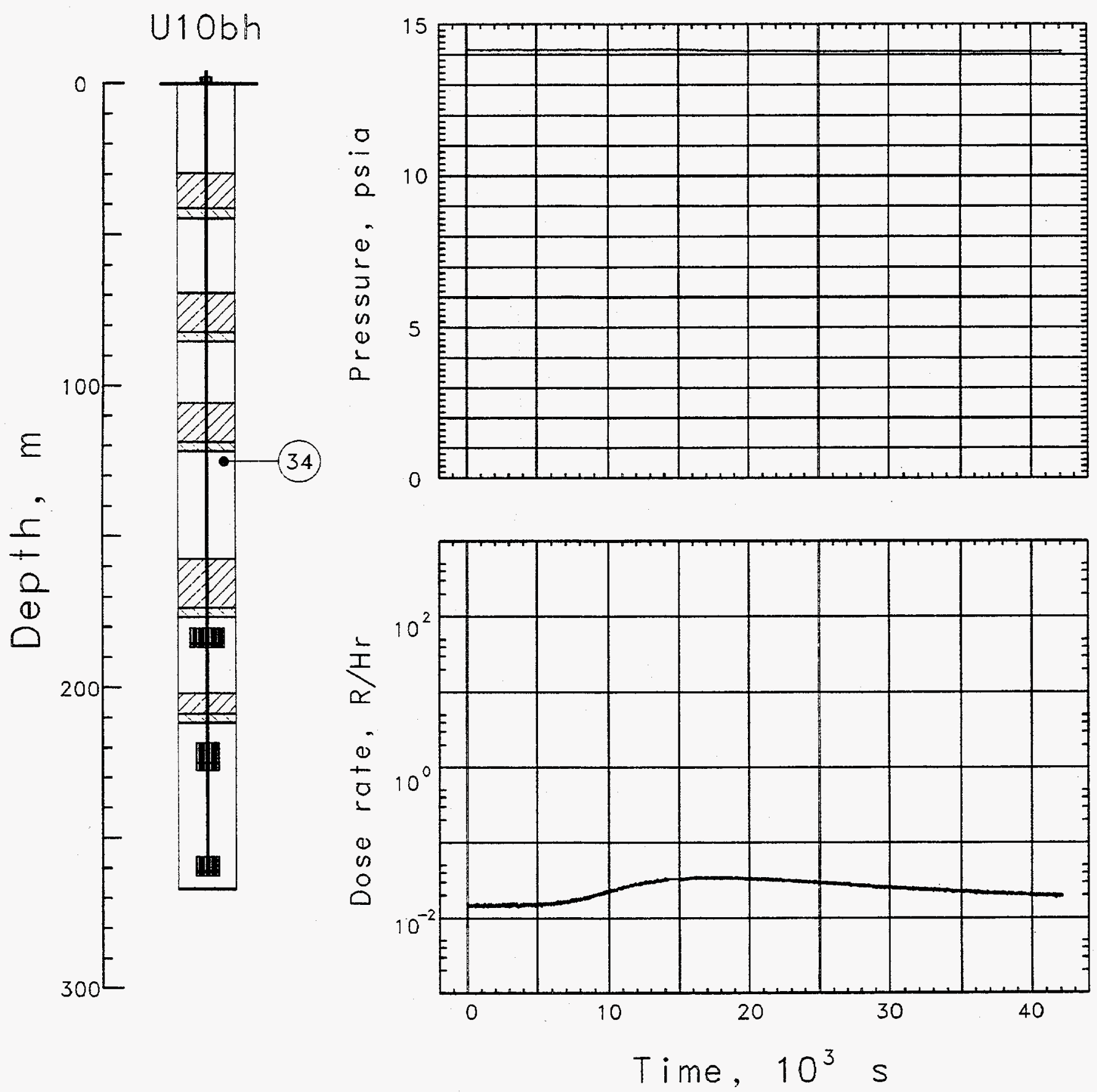

Figure 3.4 Pressure and radiation measured in the coarse stemming below SGC plug \#3 (stations 34 at $122 \mathrm{~m}$ depth and 11 at $125 \mathrm{~m}$ depth). First arrival of radiation was at about $5000 \mathrm{~s}$. 

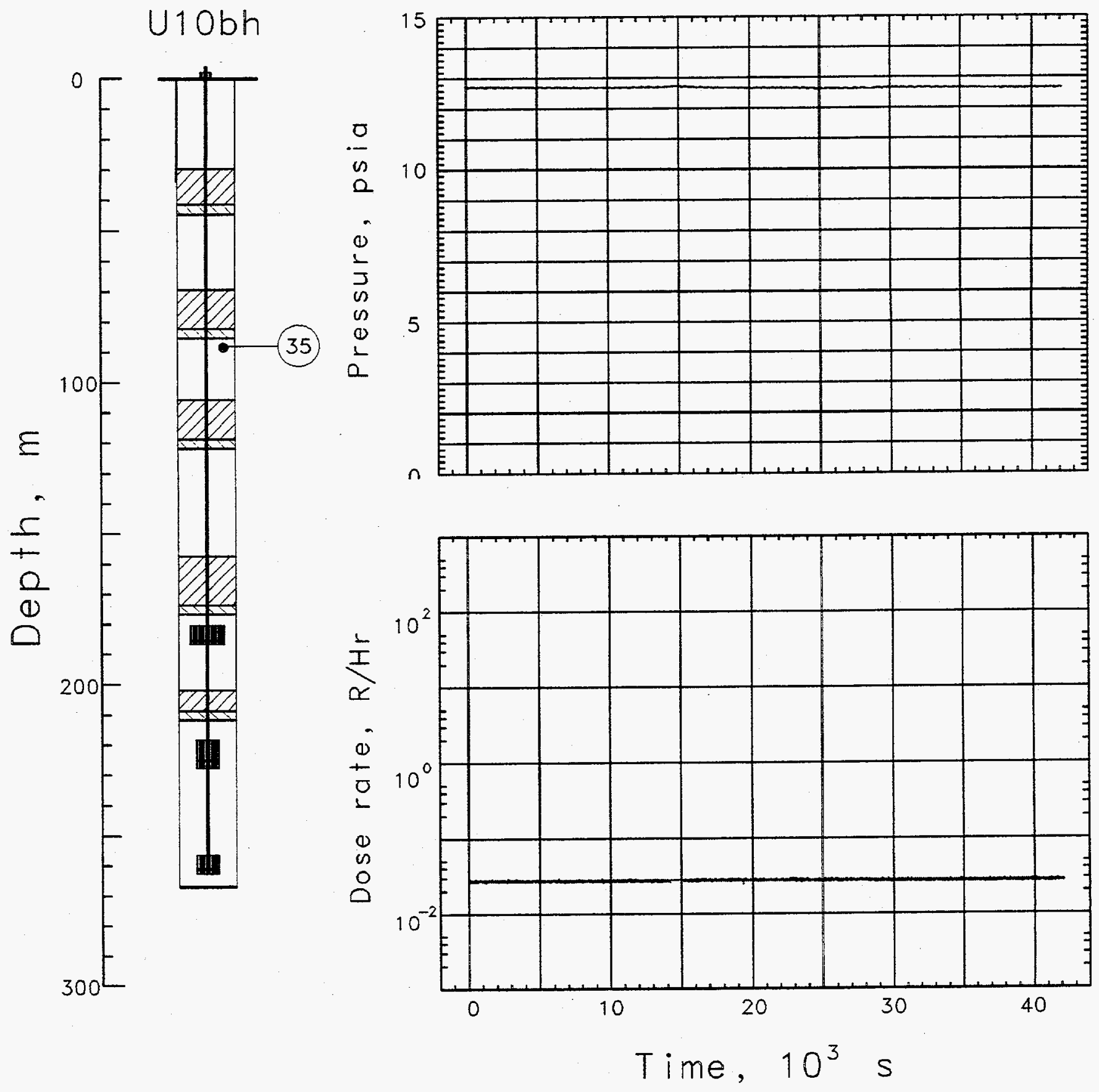

Figure 3.5 Pressure and radiation measured in the coarse stemming below SGC plug \#4 (stations 35 at $85 \mathrm{~m}$ depth and 12 at $88 \mathrm{~m}$ depth). 

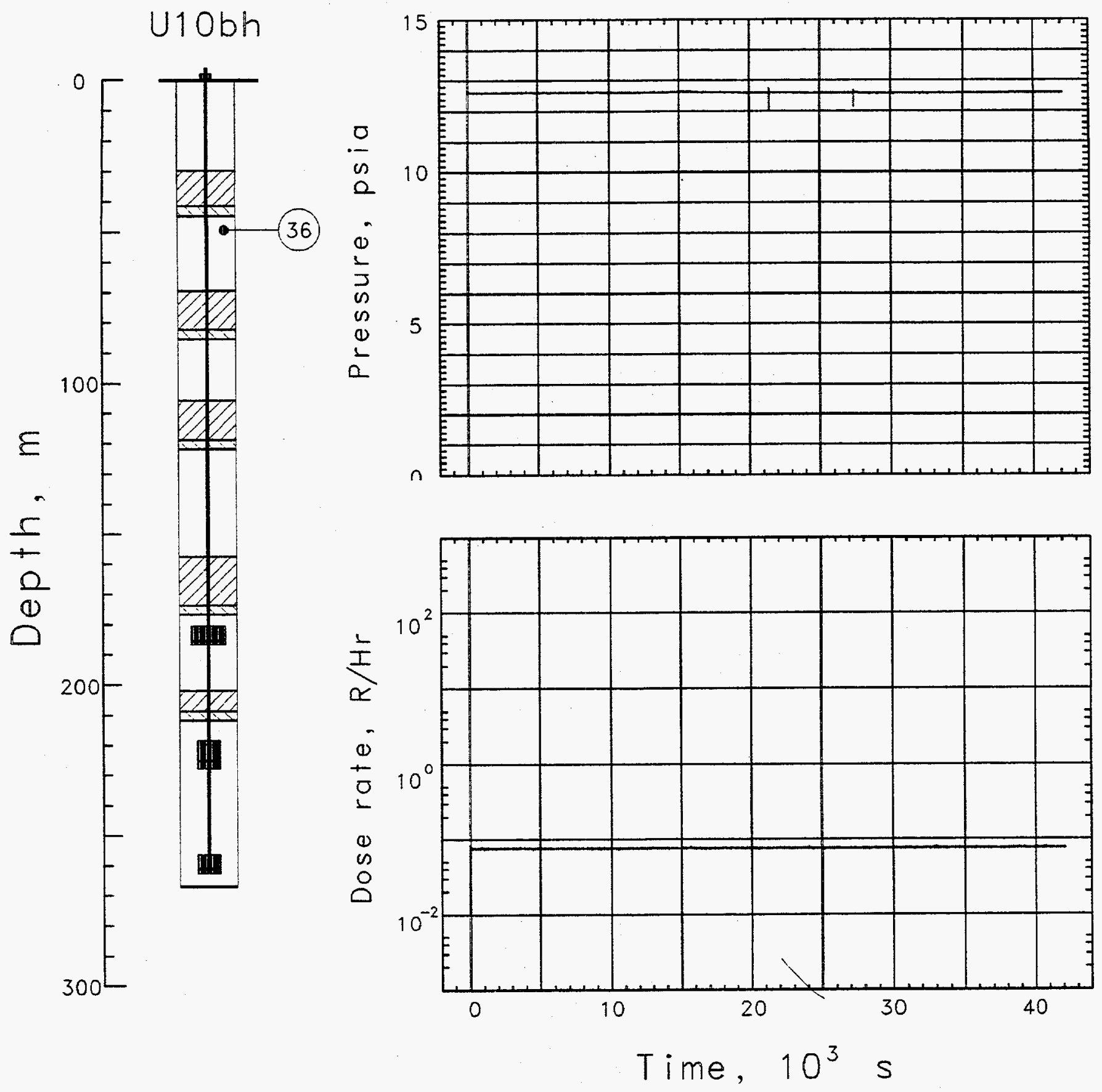

Figure 3.6 Pressure and radiation measured in the coarse stemming below SGC plug \#5 (stations 36 at $45 \mathrm{~m}$ depth and 13 at $48 \mathrm{~m}$ depth). 

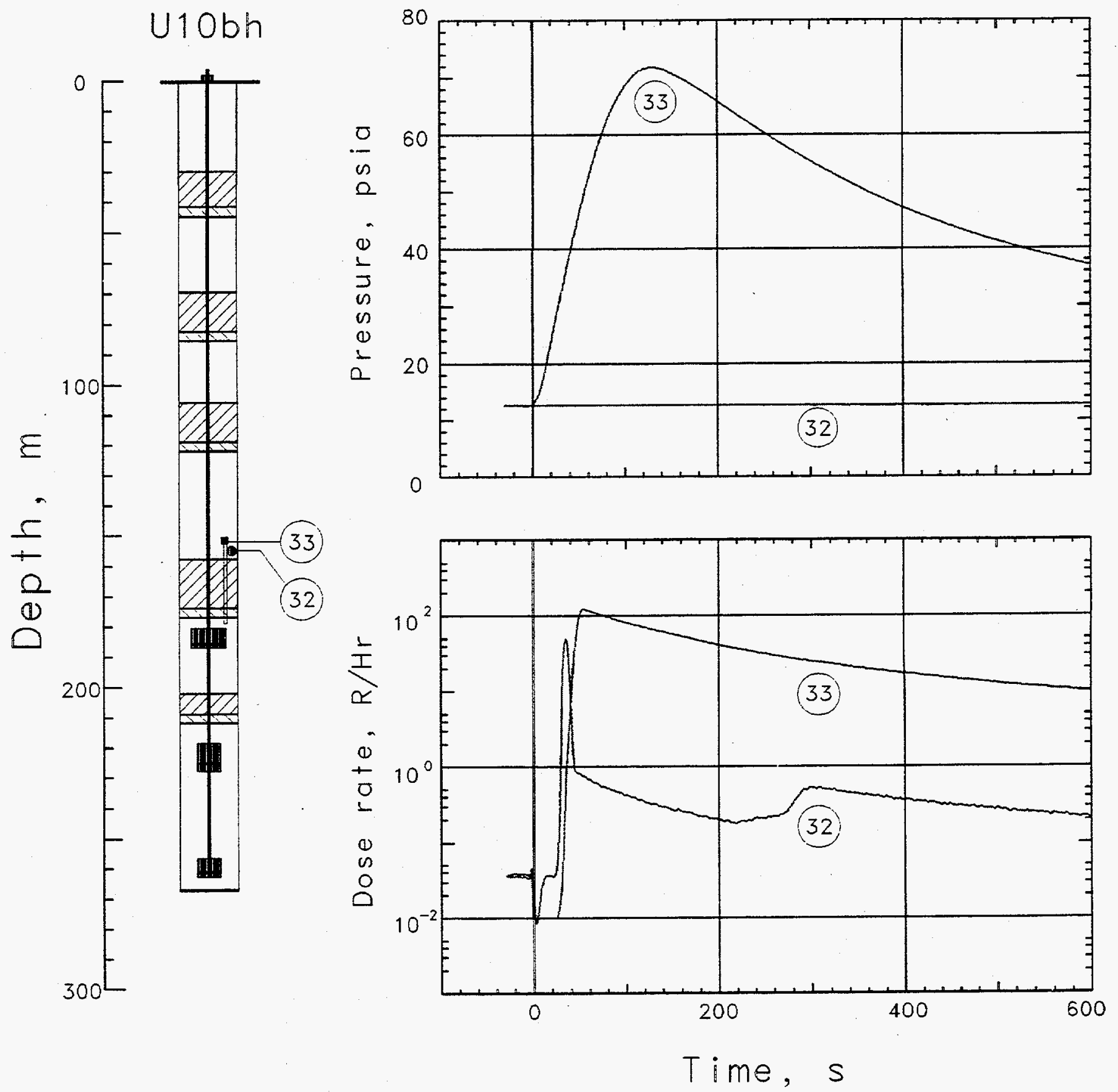

Figure 3.7 Comparison of pressures across the second plug and the radiation measured immediately above this plug. Pressure challenging the plug reached a peak of 60 psi at about $130 \mathrm{~s}$. Radiation arrived at both stations at about $22 \mathrm{~s}$. 

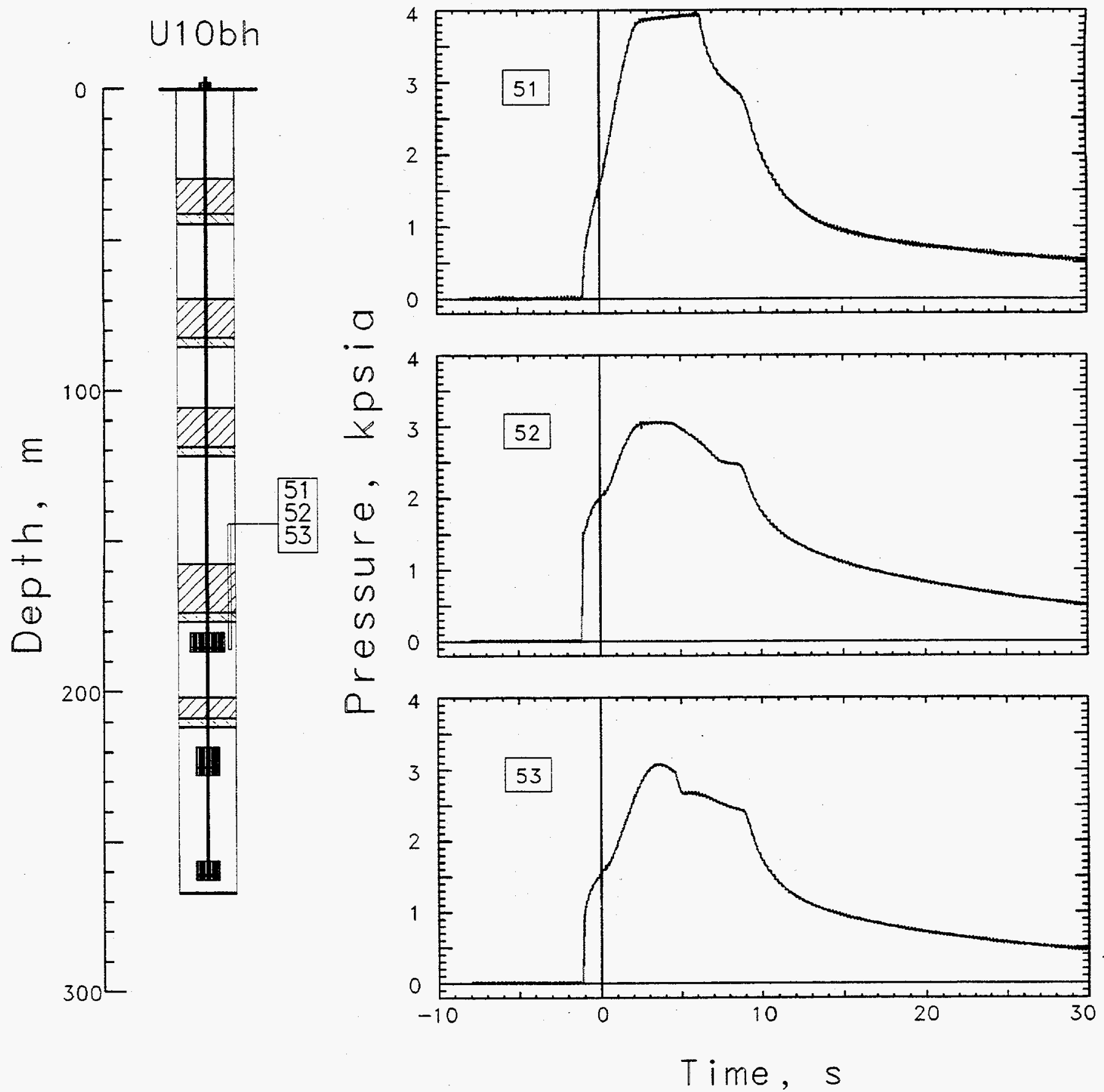

Figure 3.8 Early time wave forms of pressure measured through tubes extending from a depth of $145 \mathrm{~m}$ to near the W.P. A pressure of about 4000 psi from a 1.2 I reservoir of dry nitrogen was applied before shot time. 

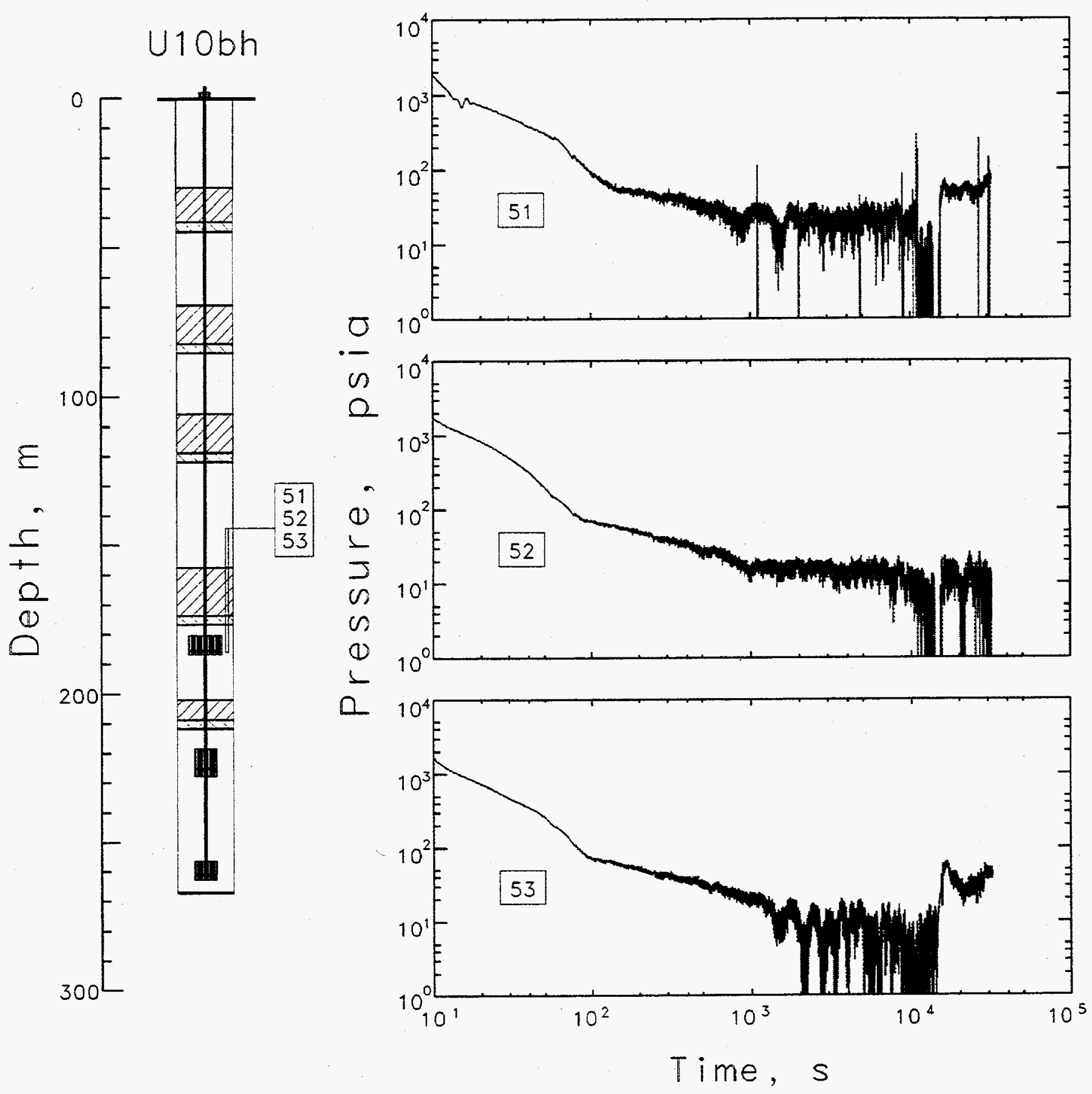

Figure 3.9 Late time wave forms of pressure measured through tubes extending from a depth of $145 \mathrm{~m}$ to near the W.P. A pressure of about 4000 psi from a 1.2 I reservoir of dry nitrogen was applied before shot time. 

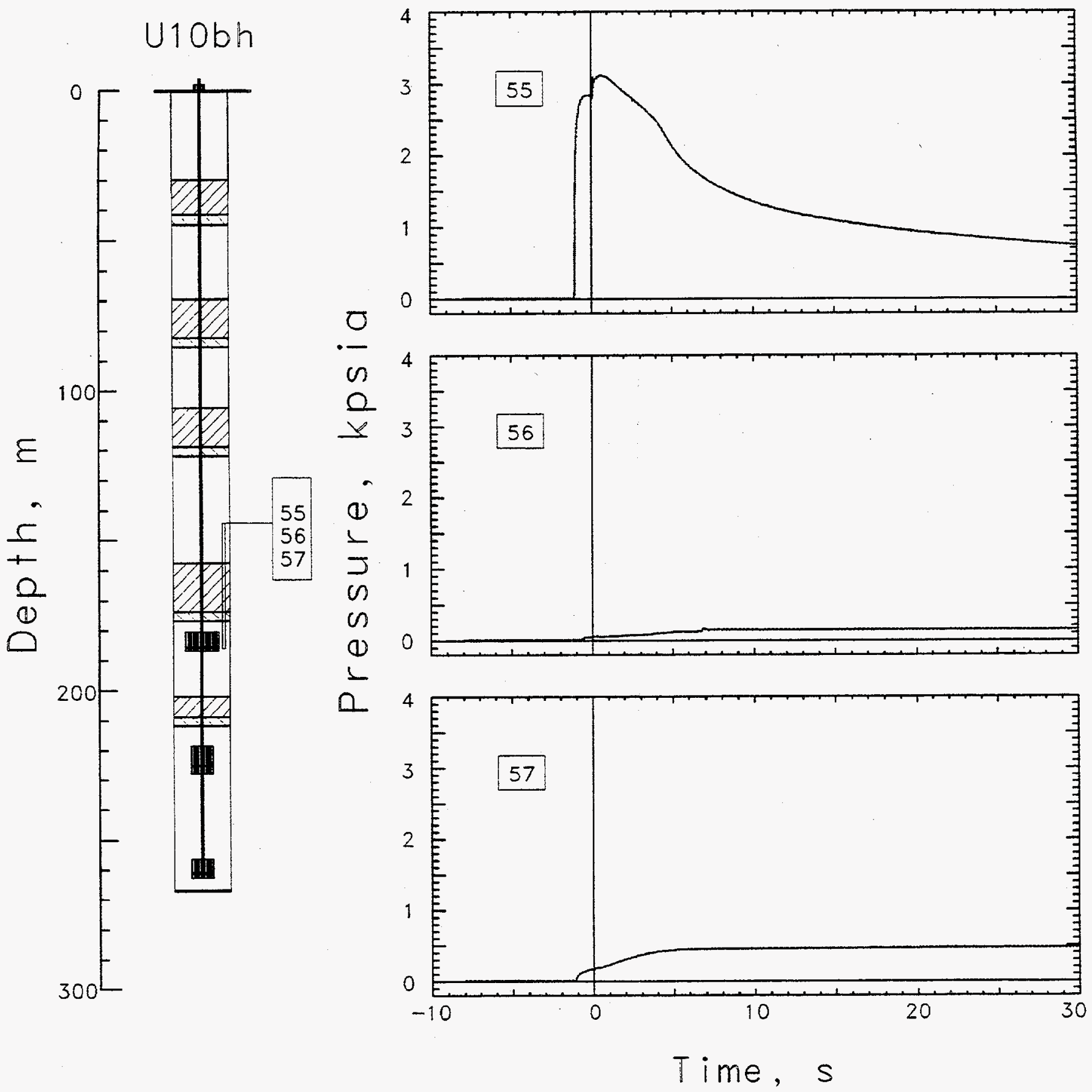

Figure 3.10 Early time wave forms of pressure measured through tubes extending from a depth of $145 \mathrm{~m}$ to near the W.P. A pressure of about 4000 psi from a 1.2 I reservoir of dry nitrogen was applied before shot time. These transducers were an extension of the gas sample system which extended upward to the radio chemistry trailer. 

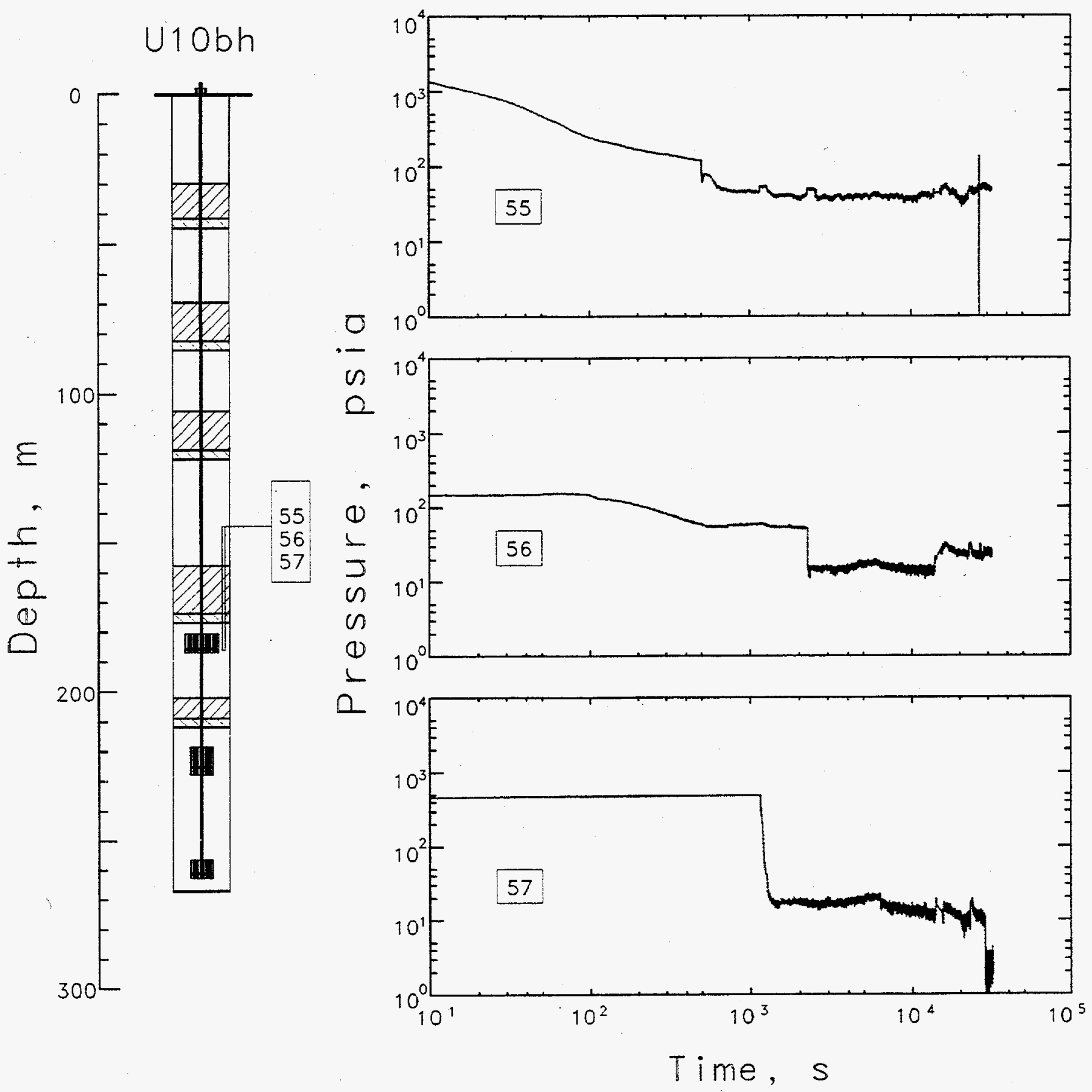

Figure 3.11 Late time wave forms of pressure measured through tubes extending from a depth of $145 \mathrm{~m}$ to near the W.P. A pressure of about 4000 psi from a 1.21 reservoir of dry nitrogen was applied before shot time. These transducers were an extension of the gas sample system which extended upward to the radio chemistry trailer. 

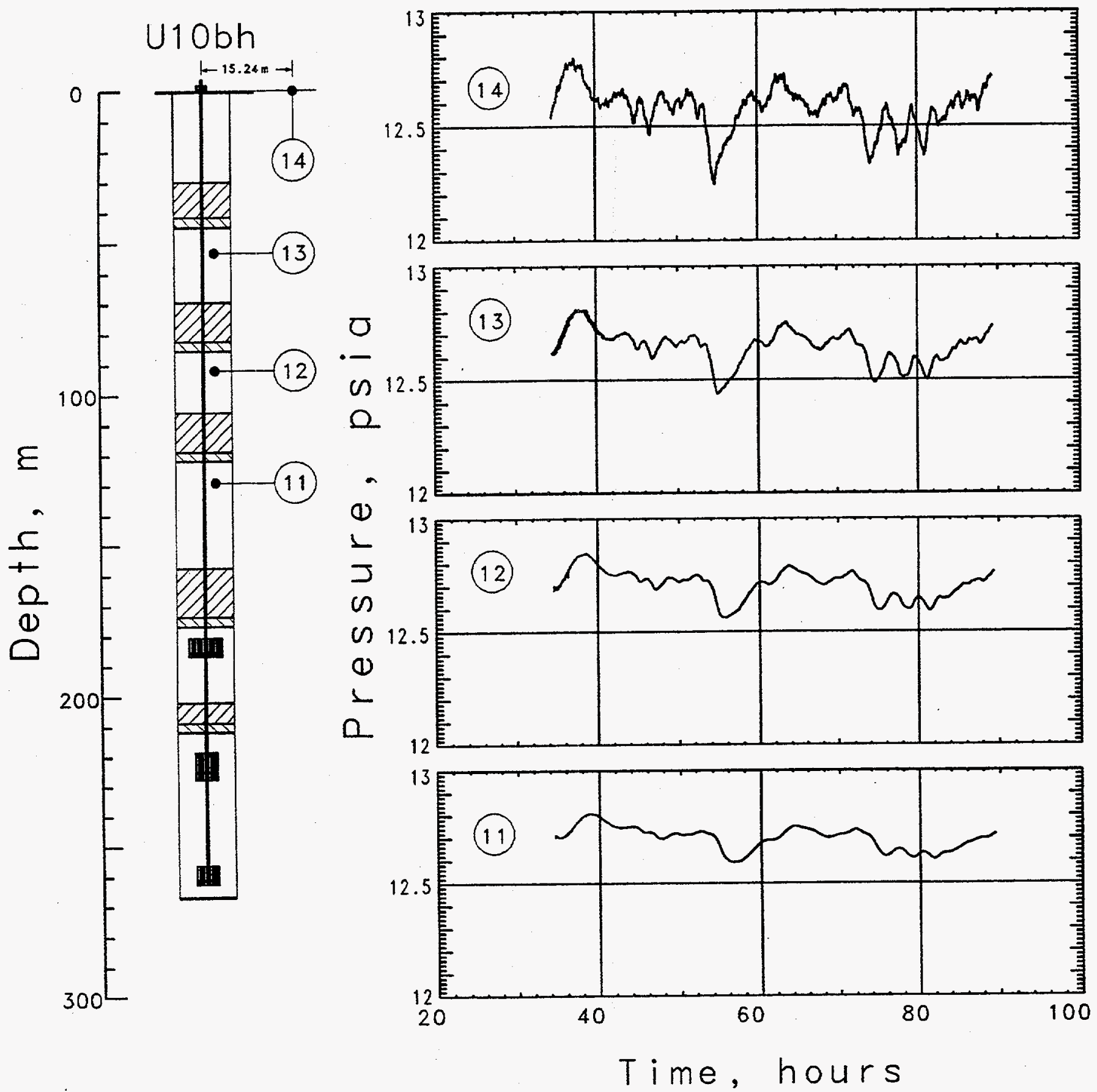

Figure 3.12 Pressures measured in the emplacement hole as a study of site permeability. 


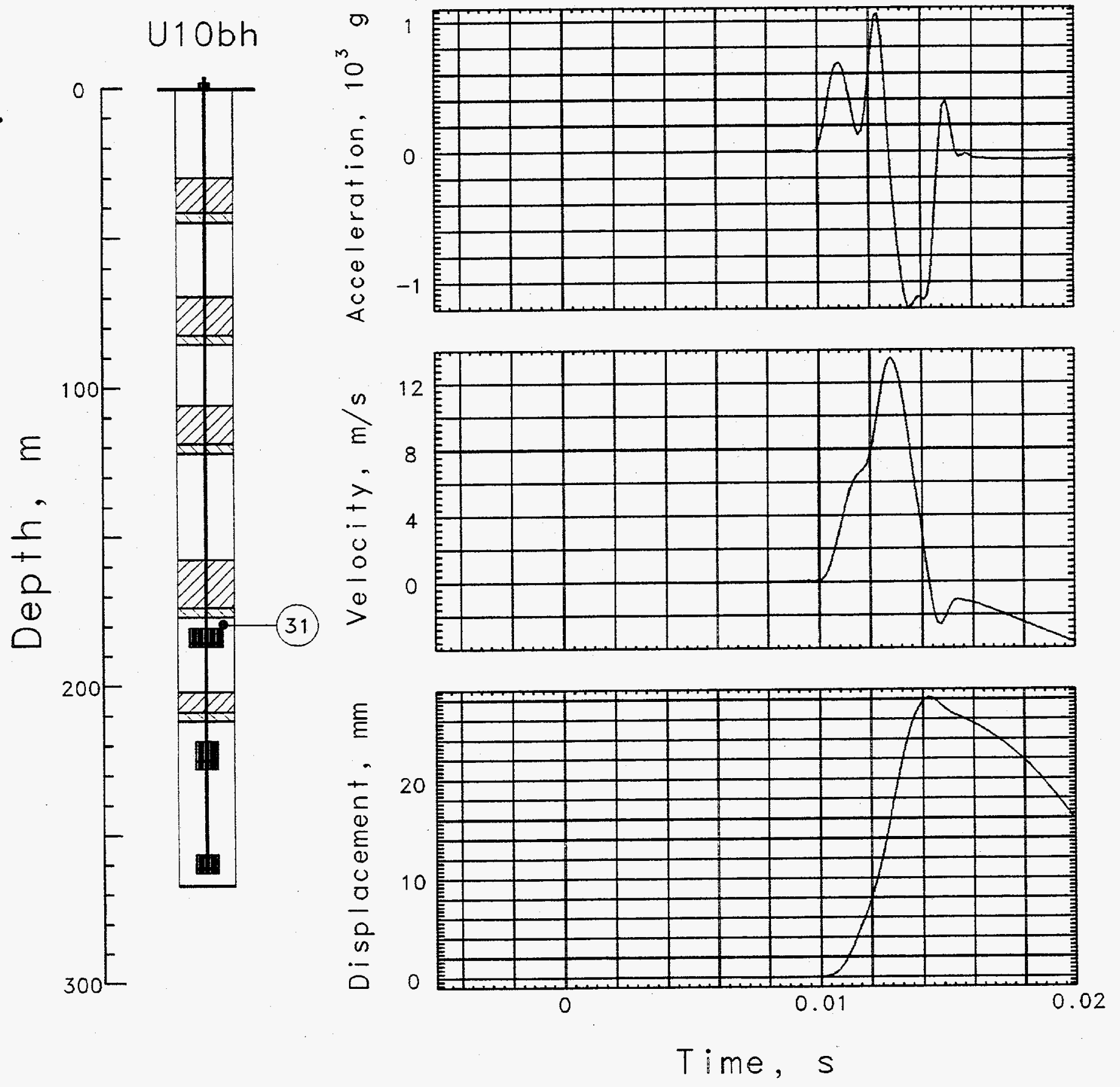

Figure 3.13 Explosion-induced vertical motion in the coarse stemming of the emplacement hole at a depth of $178 \mathrm{~m}$ (station 31, below plug \#2)). The transducer was apparently damaged at about $0.016 \mathrm{~s}$. 


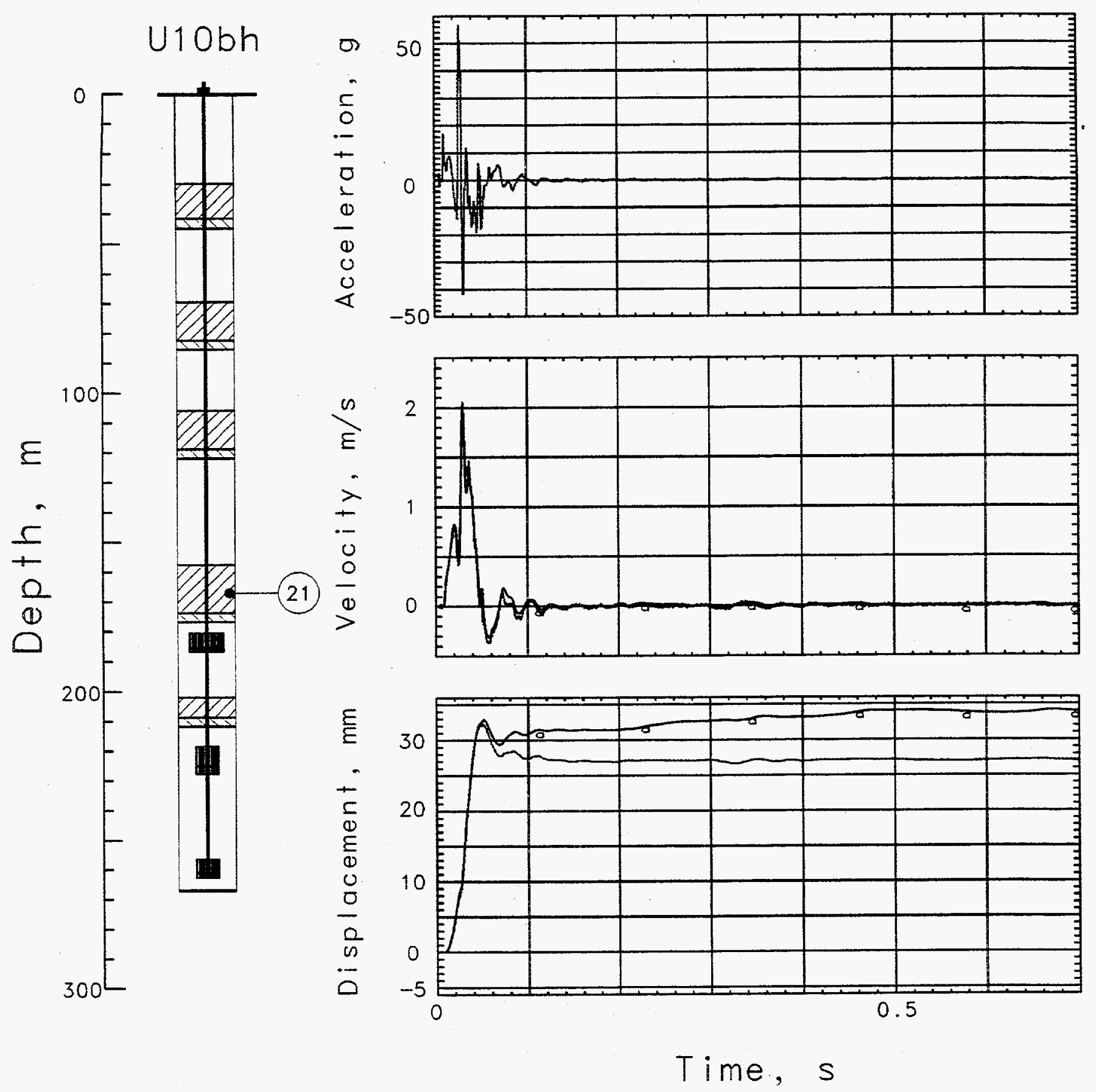

Figure 3.14 Explosion-induced vertical motion of plug \#2 at a depth of $166 \mathrm{~m}$ (station 21). Records annotated with an ' $a$ ' are derived from the accelerometer. 


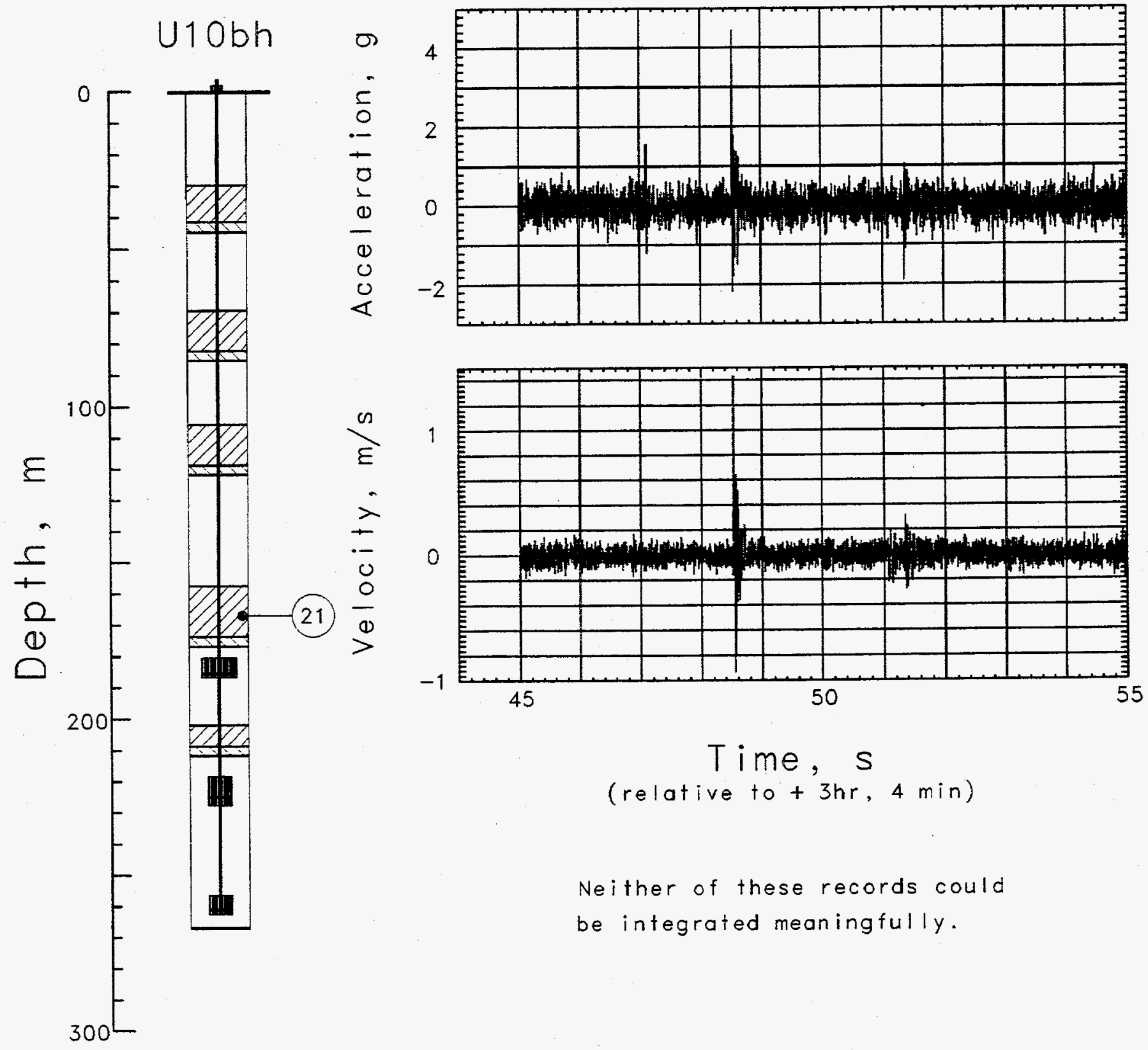

Figure 3.15 Possible collapse-induced signals in plug \#2 at a depth of $166 \mathrm{~m}$ (station 21). No discernible displacement was detected. 

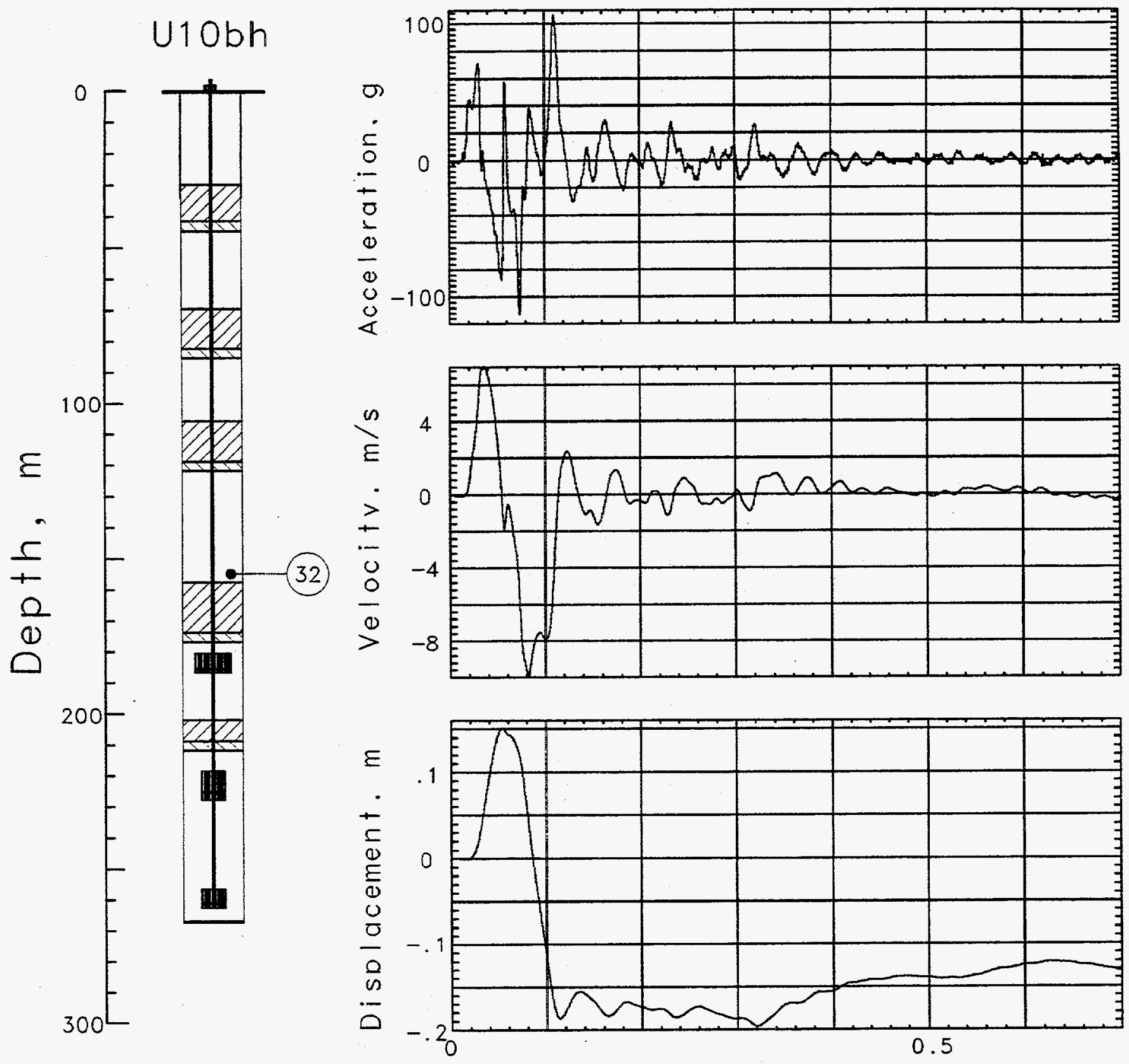

Time, s

Figure 3.16 Explosion-induced vertical motion in the coarse of the emplacement hole at a depth of $152 \mathrm{~m}$ (station 32, above plug \#2). 


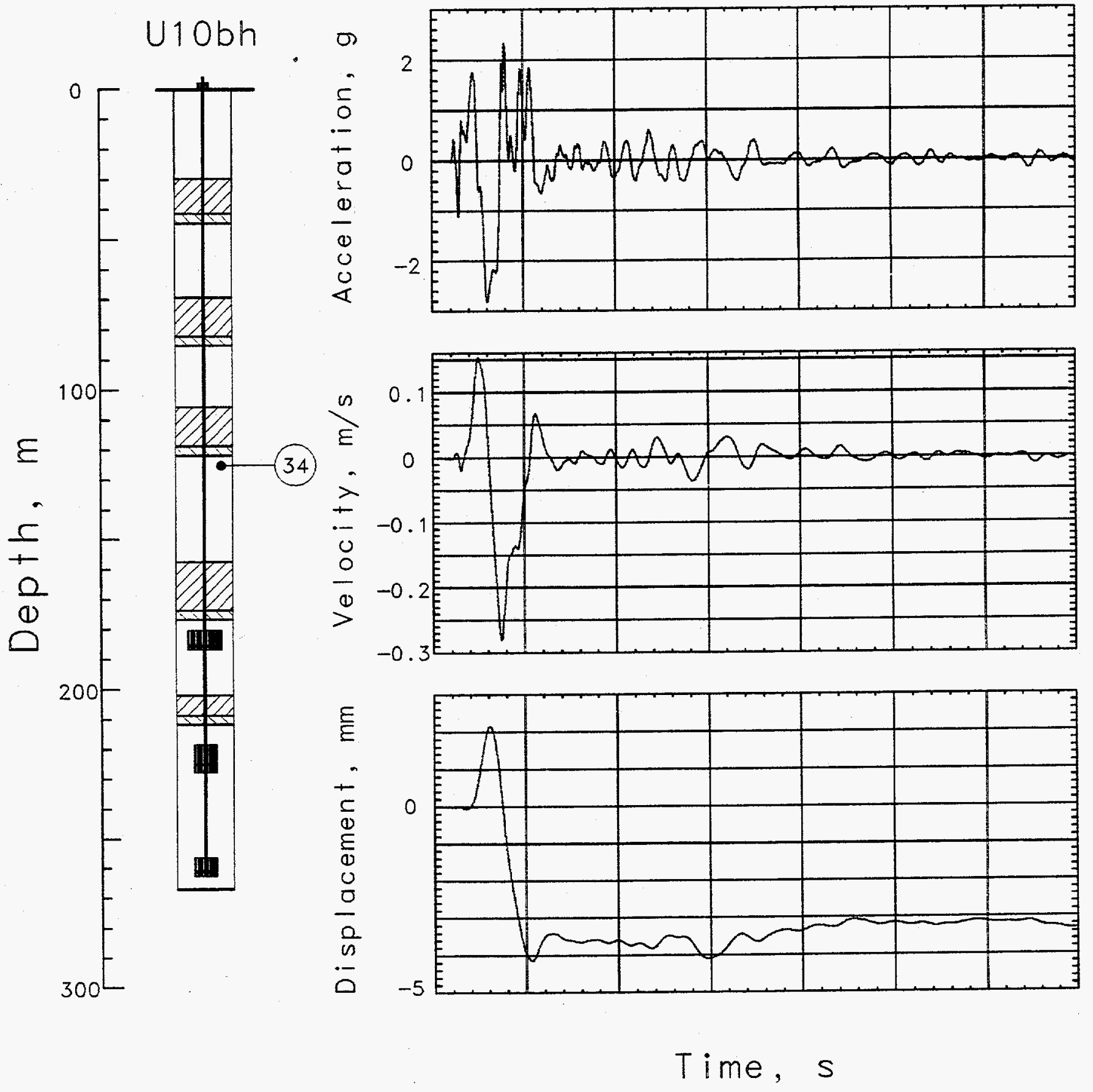

Figure 3.17 Explosion-induced vertical motion in the coarse stemming of the emplacement hole at a depth of $122 \mathrm{~m}$ (station 34, below plug \#3). 

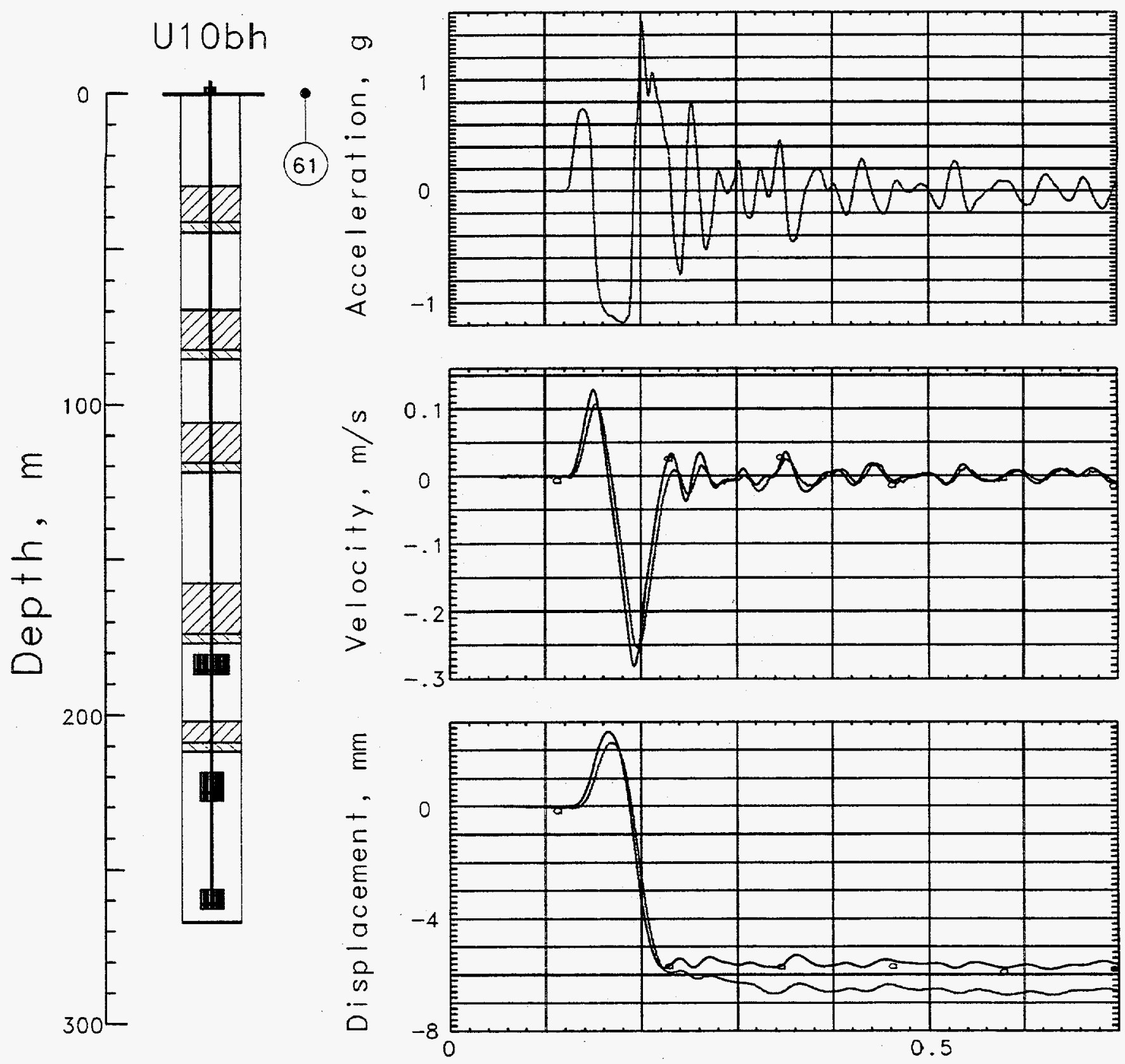

Time, s

Figure 3.18 Explosion-induced vertical motion $0.91 \mathrm{~m}$ deep in the ground surface at a horizontal distance of $15.24 \mathrm{~m}$ from Surface Ground Zero (station 61). Records annotated with an ' $a$ ' are derived from the accelerometer. 


\section{Qther Measurements}

\subsection{Motion in the LLNL trailer park}

Figures 4.1-4.3 show the explosion-induced triaxial motion of the recording trailer. Figure 4.4 shows data as recorded on a high sensitivity accelerometer and a geophone mounted in the ground surface of the trailer park (station 63). With the exception of the initial shock, the ground motion produced by HAZEBROOK was almost nonexistent. 


\section{Table 4.1 Summary of Motion}

\begin{tabular}{|c|c|c|c|c|c|c|}
\hline Gauge & $\begin{array}{l}\text { Slant Range } \\
\text { (m) }\end{array}$ & $\begin{array}{l}\text { Arrival Time } \\
\text { (ms) }\end{array}$ & $\begin{array}{l}\text { Acceleration } \\
\text { Peak (g) }\end{array}$ & $\begin{array}{l}\text { Velocity Peak } \\
\qquad(\mathrm{m} / \mathrm{s})\end{array}$ & $\begin{array}{l}\text { Displacement } \\
\text { Peak (mm) }\end{array}$ & $\begin{array}{l}\text { Displacement } \\
\text { Resid. (mm) }\end{array}$ \\
\hline $71 a v$ & $208^{(a)}$ & 140 & 0.40 & 0.041 & 1.0 & -1.2 \\
\hline $71 u v$ & & - & - & 0.042 & 1.0 & -0.5 \\
\hline $71 \operatorname{ar}^{(b)}$ & $208^{(a)}$ & 145 & 0.45 & 0.046 & 0.5 & -1.4 \\
\hline $71 u^{(b)}$ & & - & - & 0.10 & 1.7 & -3 \\
\hline 71at & $208^{(a)}$ & 145 & 0.20 & 0.013 & $2^{(c)}$ & (c) \\
\hline 71ut & & - & - & 0.013 & $0.3,-0.4$ & -0.1 \\
\hline
\end{tabular}

(a) Range is approximate: station is in trailer.

(b) Difference in wave form amplitudes is probably due to a calibration error.

(c) Baseline offset very difficult to remove.

Table 4.2 Accelerometer Characteristics

\begin{tabular}{lcccc} 
Gauge & $\begin{array}{c}\text { Natural Frequency } \\
(\mathrm{Hz})\end{array}$ & Damping Ratio & $\begin{array}{c}\text { System Range } \\
\text { (g's) }\end{array}$ \\
\cline { 1 - 2 } 71av & 330 & & 0.70 & 20 \\
71ar & 340 & 0.70 & 15 \\
71 at & 310 & 0.67 & 15
\end{tabular}

Table 4.3 Velocimeter Characteristics

\begin{tabular}{|c|c|c|c|c|c|}
\hline Gauge & $\begin{array}{c}\text { Natural } \\
\text { Frequency } \\
(\mathrm{Hz})\end{array}$ & $\begin{array}{l}\text { Time to } 0.5 \\
\text { Amplitude } \\
\text { (s) }\end{array}$ & $\begin{array}{c}\text { Calibration } \\
\text { Temperature } \\
\left({ }^{\circ} \mathrm{C}\right)\end{array}$ & $\begin{array}{c}\text { Operate } \\
\text { Temperature } \\
\left({ }^{\circ} \mathrm{C}\right)\end{array}$ & $\begin{array}{c}\text { System } \\
\text { Range } \\
(\mathrm{m} / \mathrm{s})\end{array}$ \\
\hline 71 uv & 3.253 & 12.03 & 24.42 & 20.15 & 7 \\
\hline $71 u r$ & 3.516 & 9.59 & 24.42 & 20.15 & 5 \\
\hline 71ut & 3.354 & 8.87 & 25.41 & 20.15 & 5 \\
\hline
\end{tabular}



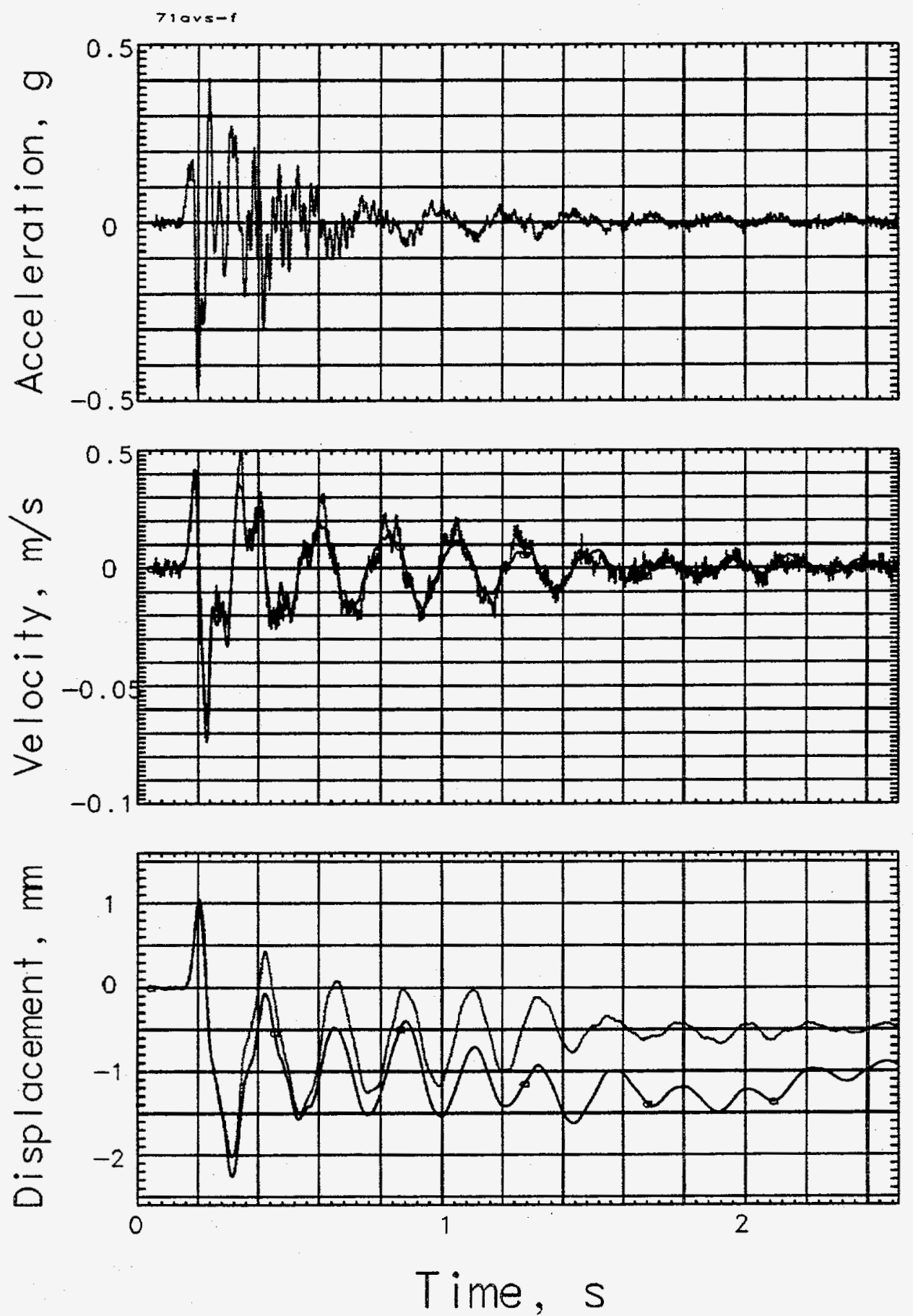

Figure 4.1 Explosion-induced vertical motion of the recording trailer (station 71). Records annotated with an ' $a$ ' are derived from the accelerometer. 

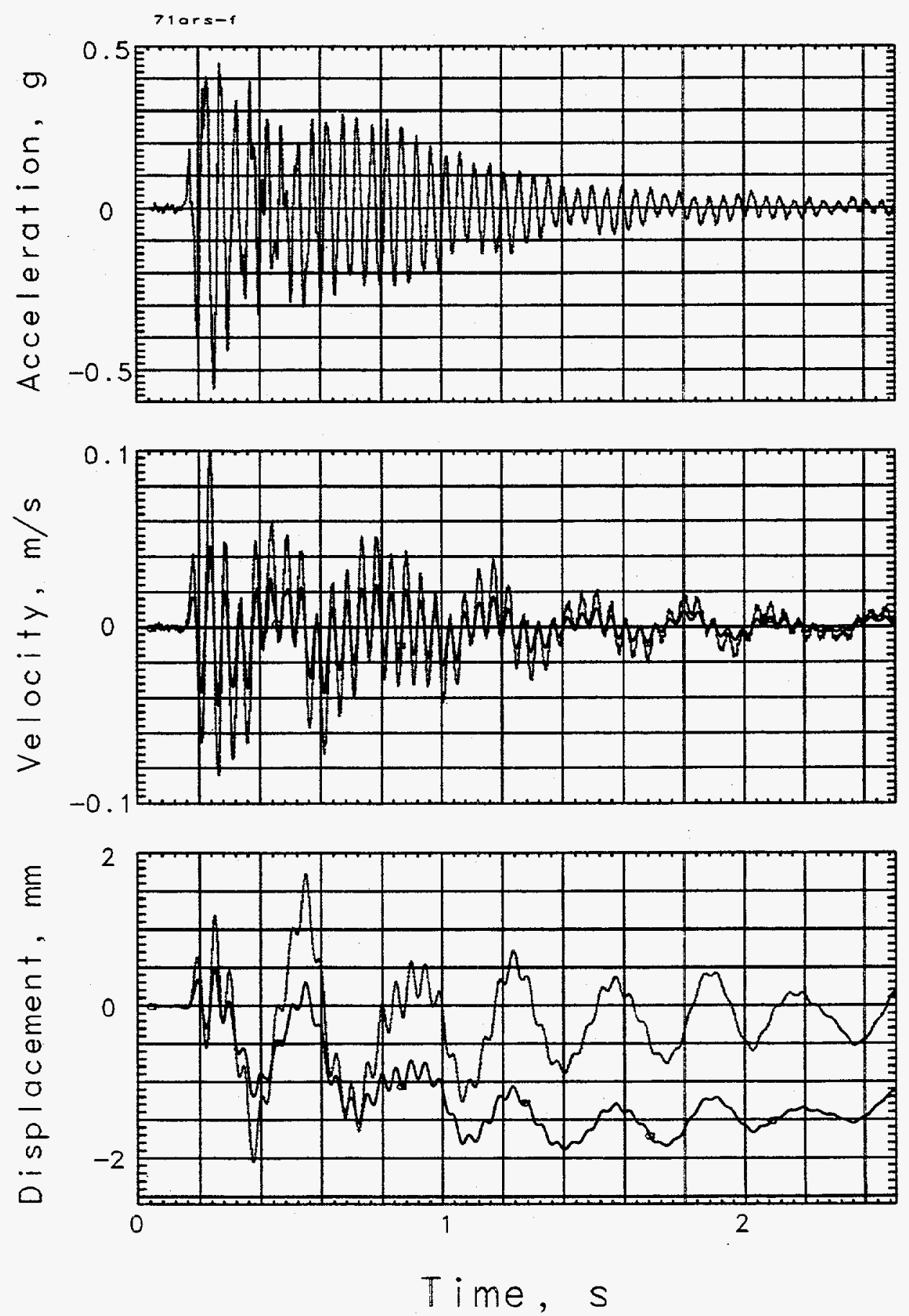

Figure 4.2 Explosion-induced horizontat-radial motion of the recording trailer (station 71). Records annotated with an ' $a$ ' are derived from the accelerometer. 

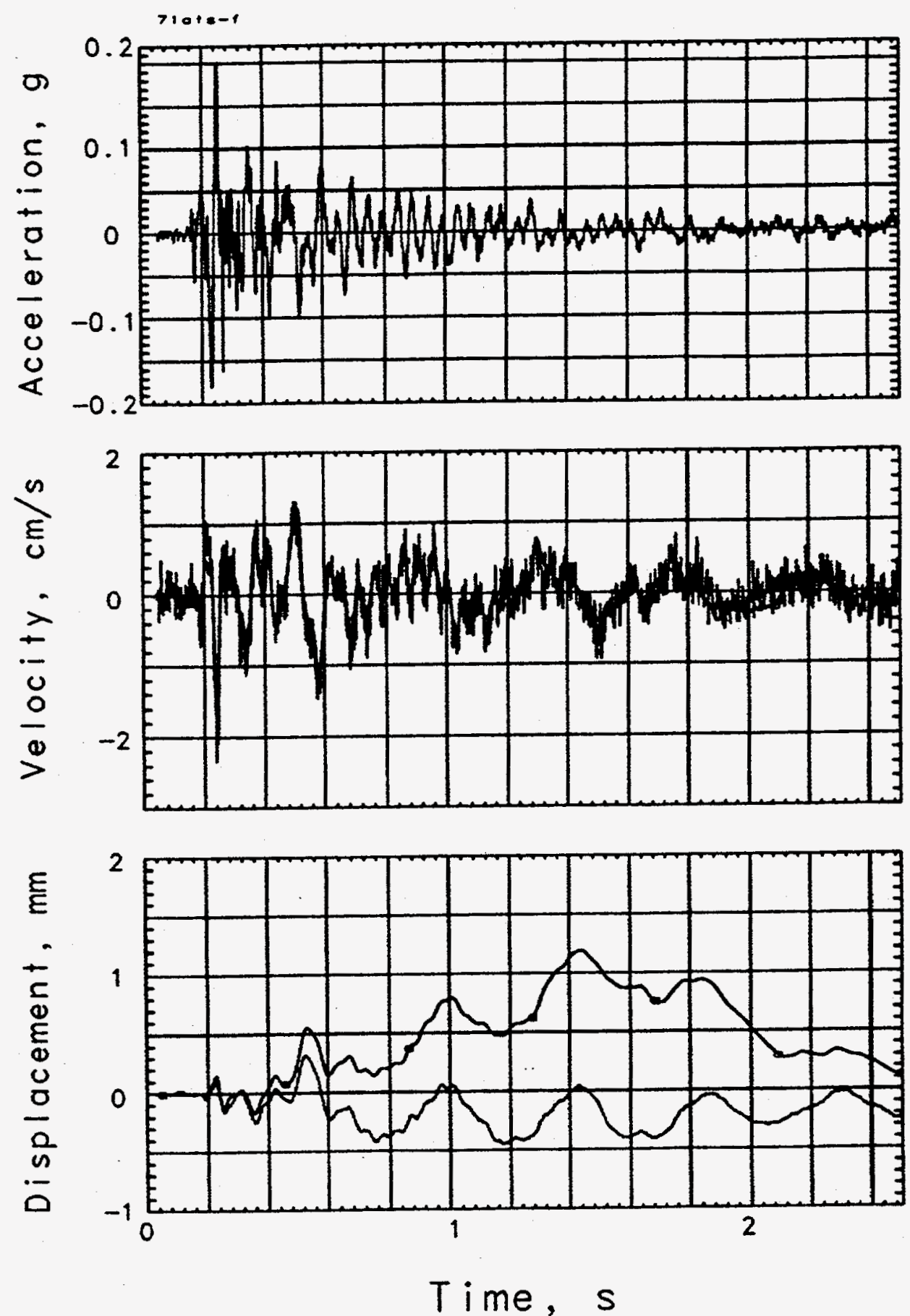

Figure 4.3 Explosion-induced horizontal-transverse motion of the recording trailer (station 71). Records annotated with an 'a' are derived from the accelerometer. 

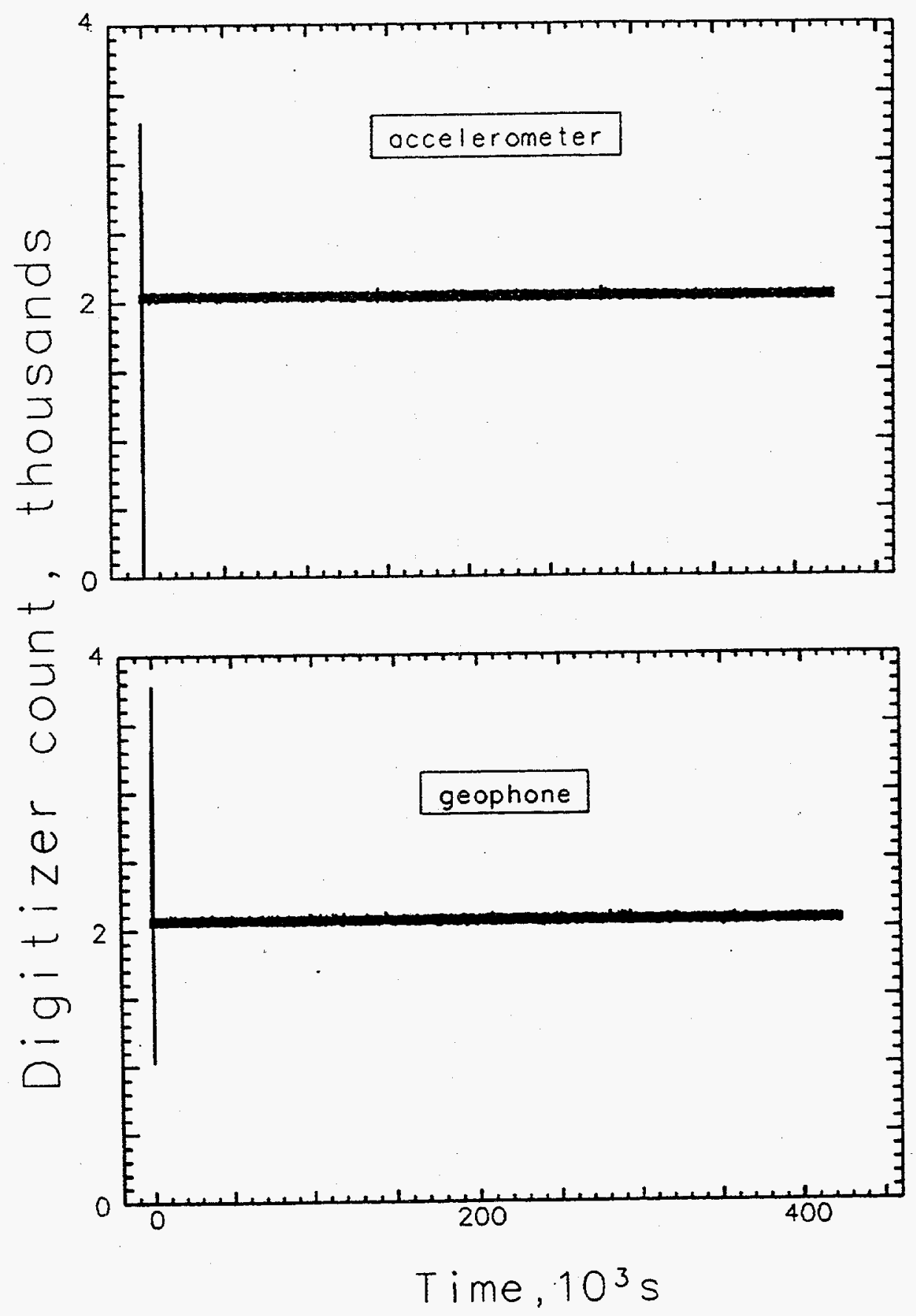

Figure 4.4 Data from the vertical geophone and sensitive accelerometer mounted in the ground surface at the recording trailer (station 63). Note that there is no detectable motion after the first explosion-induced shock. 


\section{References}

1. Stephen Clark and Casey Schmidt, "U10bh Site Characteristics Report", CP 86-44, Lawrence Livermore National Laboratory, Livermore, CA, July 21, 1986.

2. R. Hutchinson for Alfred E. Burer, "Emplacement and Containment Report for HAZEBROOK U10bh", Holmes \& Narver, NTS:A2:87-12, February 2,1987.

3. LLNL contacts for additional information: R. Heinle (CORRTEX data).

4. Richard A. Spilsbury, "Special Measurements Final Engineering Report for HAZEBROOK, U10bh," EG\&G, Energy Measurements, Las Vegas, NV, SM:87E-139-30, 27 March, 1987.

5. Richard A. Spilsbury, "Special Measurements Physics/Instrumentation Package for HAZEBROOK, U10bh, Final"' EG\&G, Energy Measurements, Las Vegas, NV, SM:86E-139-29, 11 February, 1987. 
Distribution:

LLNL

TID (11)

Test Program Library

Containment Vault

Burkhard, N.

Cooper, W.

Denny, $M$.

Dong, R.

Goldwire, $H$.

Heinle, R. (5)

Mara, G.

Moran, M.T.

Moss, $W$.

Olsen, $\mathrm{C}$.

Patton, $\mathrm{H}$,

Pawloski, G.

Rambo, J.

Roland, $\mathrm{K}$.

Roth, B.

Valk, $T$.

Younker, L.

LANL

App, F.

Brunish, $W$.

Kunkle, $T$.

Trent, B.

\section{Sandia}

Chabai, A.

Smith, Carl W.
L-053

L- 045

L-221

L-221

L-049

L-205

L-140

L-221

$L-221$

L-049

L-777

L-200

$L-221$

L-205

L-221

L-200

L-221

L-049

L-154

L-203

F-659

F-659

F-665

F-664

MS-1159

MS-1159
EG\&G/AVO

Brown, $T$.

Gilmore, $L$.

A-5

Hatch, $M$.

Still, $G$.

Stubbs, T.

A-1

A- 5

A-5

A-5

EG\&G/NVO

Bellow, B.

N 13-20

Davies, L.

N 13-20

Moeller, A.

Robinson, R.

$N 13-20$

N 13-20

Webb, W.

N 13-20

DNA

Ristvet, B.

S-Cubed

Peterson, E.

Eastman Cherrington Environment 1640 Old Pecos Trail, Suite H Santa Fe, NM 87504

Keller, C. 